\title{
Echinacoside, an Inestimable Natural Product in Treatment of Neurological and other Disorders
}

\author{
Jingjing Liu ${ }^{1,+}$, Lingling Yang ${ }^{1,+}$, Yanhong Dong ${ }^{1}$, Bo Zhang ${ }^{1}$ and Xueqin Ma ${ }^{1,2, *(1)}$ \\ 1 Department of Pharmaceutical Analysis, School of Pharmacy, Ningxia Medical University, 1160 Shenli Street, \\ Yinchuan 750004, China; 15709604029@163.com (J.L.); 15926361499@163.com (L.Y.); \\ dyh794200808@163.com (Y.D.); zhangbobo0624@163.com (B.Z.) \\ 2 Key Laboratory of Hui Ethnic Medicine Modernization, Ministry of Education, Ningxia Medical University, \\ 1160 Shenli Street, Yinchuan 750004, China \\ * Correspondence: maxueqin217@126.com; Tel.: +86-951-6880693 \\ + These authors contributed equally to this work.
}

Academic Editors: Nancy D. Turner and Isabel C. F. R. Ferreira

Received: 1 May 2018; Accepted: 15 May 2018; Published: 18 May 2018

check for updates

\begin{abstract}
Echinacoside $(\mathrm{ECH})$, a natural phenylethanoid glycoside, was first isolated from Echinacea angustifolia DC. (Compositae) sixty years ago. It was found to possess numerous pharmacologically beneficial activities for human health, especially the neuroprotective and cardiovascular effects. Although ECH showed promising potential for treatment of Parkinson's and Alzheimer's diseases, some important issues arose. These included the identification of active metabolites as having poor bioavailability in prototype form, the definite molecular signal pathways or targets of ECH with the above effects, and limited reliable clinical trials. Thus, it remains unresolved as to whether scientific research can reasonably make use of this natural compound. A systematic summary and knowledge of future prospects are necessary to facilitate further studies for this natural product. The present review generalizes and analyzes the current knowledge on ECH, including its broad distribution, different preparation technologies, poor pharmacokinetics and kinds of therapeutic uses, and the future perspectives of its potential application.
\end{abstract}

Keywords: echinacoside; preparation; pharmacokinetics; Parkinson's disease; Alzheimer's disease

\section{Introduction-Treasure from the Garden: The Discovery and Distribution of ECH}

Phenylethanoid glycosides (PhGs) are naturally occurring water-soluble compounds that are widely distributed in the plant kingdom, and most of which are isolated from garden plants and medicinal herbs. Structurally, these compounds are characterized by cinnamic acid and hydroxyl phenyl ethyl moieties that are attached to a $\beta$-glucopyranose (apiose, galactose, rhamnose, xylose, etc.) via a glycosidic bond. In recent years, interest has been growing in using PhGs [1] as their potential in the prevention and treatment of various human diseases and disorders.

Echinacoside (ECH, Figure 1), a natural PhG, was first isolated from Echinacea angustifolia DC. (Compositae), a garden plant sixty years ago, [2] and subsequently prepared from the species of Cistanches [3] as well as the aerial part of landscape herb, Penstemon crandallii A. Nels. (Scrophulariaceae) [4], whole plants of Pedicularis striata Pall. [5] and now successively found in 40 plant species [6-12] belonging to 18 genus and 10 families (Figure 2). To date, the species of genus Cistanches (Orobanchaceae) and Echinacea (Asteraceae) were the main natural plant sources for the preparation of $\mathrm{ECH}$. 
<smiles>CC1OC(OC2C(O)C(OCCc3ccc(O)c(O)c3)OC(COC3OC(CO)C(O)C(O)[C@H]3O)C2OC(=O)/C=C/c2ccc(O)c(O)c2)[C@H](O)[C@@H](O)C1O</smiles>

Figure 1. Chemical structure of Echinacoside (ECH) (Glu-Glu-Rha).

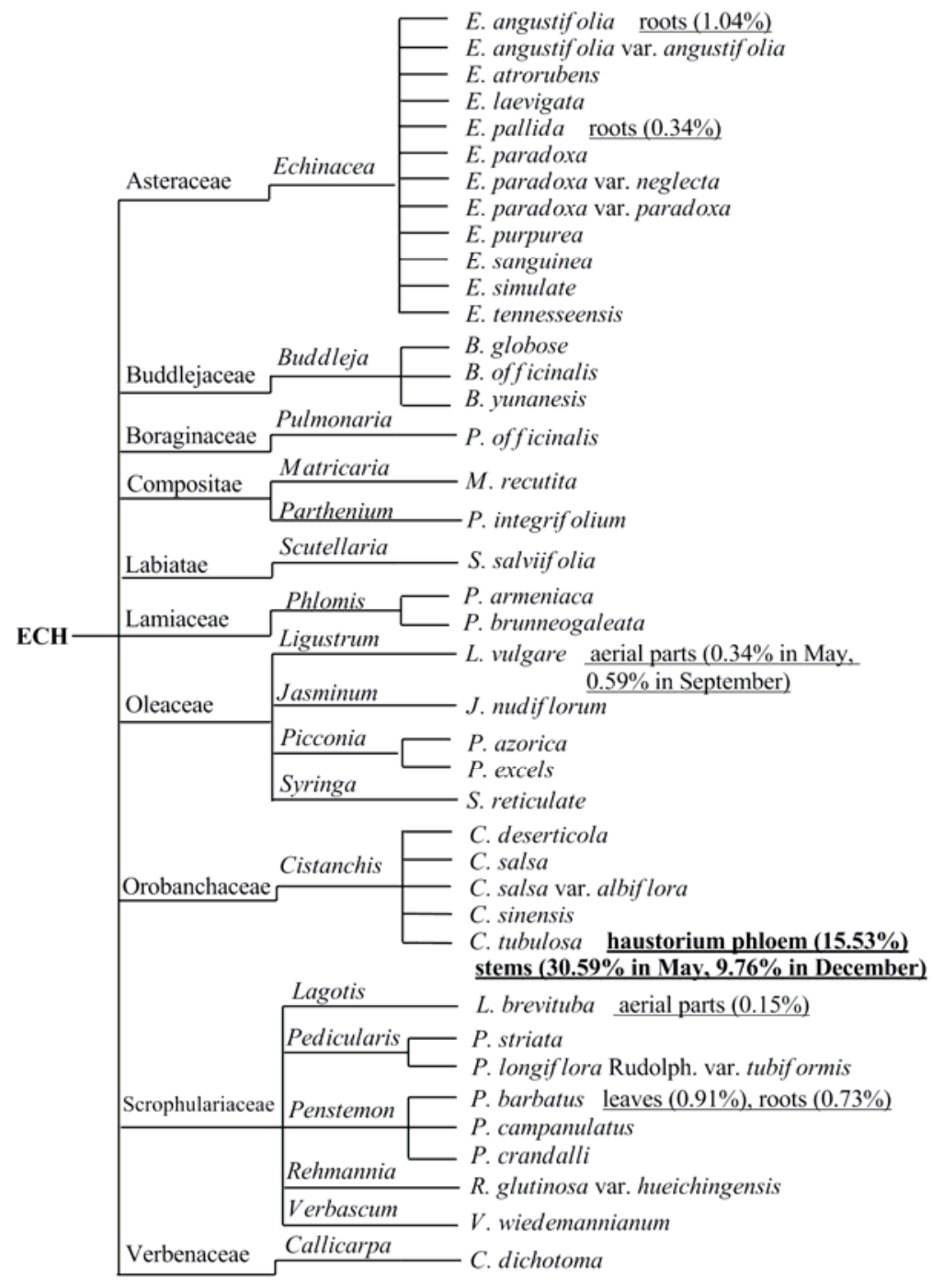

Figure 2. The broad distribution and discovery of $\mathrm{ECH}$ in the plant kingdom.

ECH was found in both underground and aboveground parts of medicinal herbs but with widely varying levels of content (Figure 2), including different stages of plant growth [8,13], different parts of the same plant [14], and vice versa, the same parts of different plants [15,16]. Until now, the highest 
content of ECH was found in haustorium phloem of Cistanches tubulosa which was reached almost $15.5 \%$ [17], thus could be a good resource for the isolation of pure ECH.

\section{Preparation of ECH}

As PhG compounds exhibited significant activities in the prevention and treatment of various human diseases and disorders, it was important to develop sustainable methods to produce sufficient quantities of ECH for pharmaceutical applications. Firstly and also usually, like other natural bioactive compounds, high purity of ECH was obtained from medicinal plants by using classic isolation methods and semi-preparative liquid chromatography (LC) [18] or high-speed counter-current chromatography methods [14] as Figure 3 shown, and the yield of ECH was usually between $0.2 \% \sim 0.4 \%$. An efficient ultrasound-assisted aqueous two-phase extraction process for preparation of ECH from Cistanche deserticola enhanced the content of ECH in the extracts $(27.56 \mathrm{mg} / \mathrm{g})$ which was 2.46 -fold higher than the amounts obtained in ultrasound-assisted extraction [19]. Interestingly, it was found the content of ECH in medicinal herbs was significantly influenced by the factors of preparation processing [20], including the slice thickness, drying temperature, and the time for inactivation of the enzyme [21]. Therefore, it was worth noting that ECH was demonstrated to be highly susceptible to "enzymic" degradation and oxidation in hydroalcoholic solutions during the extraction process, and ECH in biosamples was susceptible to degradation at a higher temperature during the whole process, thus the operation must be carried out carefully at a lower temperature. Secondly, besides the above classic isolation method, plant cell/tissue culture, called "green cell factories", has become increasingly attractive as a cost-effective alternative to classical approaches for the sustainable mass production of plant-derived molecules [22]. Several published data demonstrated an increased accumulation of ECH in both plant tissue culture [23] and cell suspension culture [24] of Cistanche deserticola, and some revulsant including tyrosine, phenylalanine, cladosporium fulvum, methyl jasmonate and salicylic acid were found could promote the accumulation of ECH [25-27]. Thirdly, as an inestimable natural product which possesses a broad spectrum of beneficial activities, the chemical synthesis of ECH is needed to satisfy its comprehensive application. A group from National Taiwan University has completed the total synthesis of ECH from building blocks over 7 steps with yield was 4.5\% [28] which was showed in Figure 3.

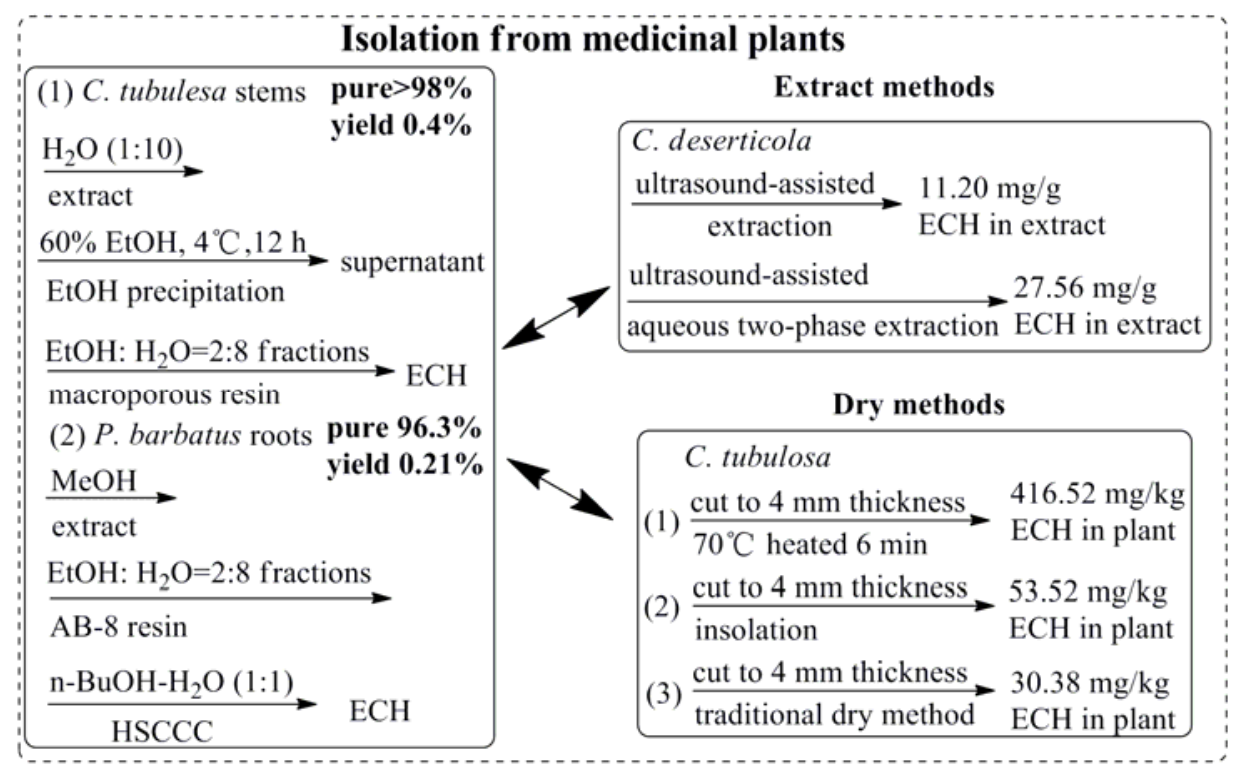

Figure 3. Cont. 


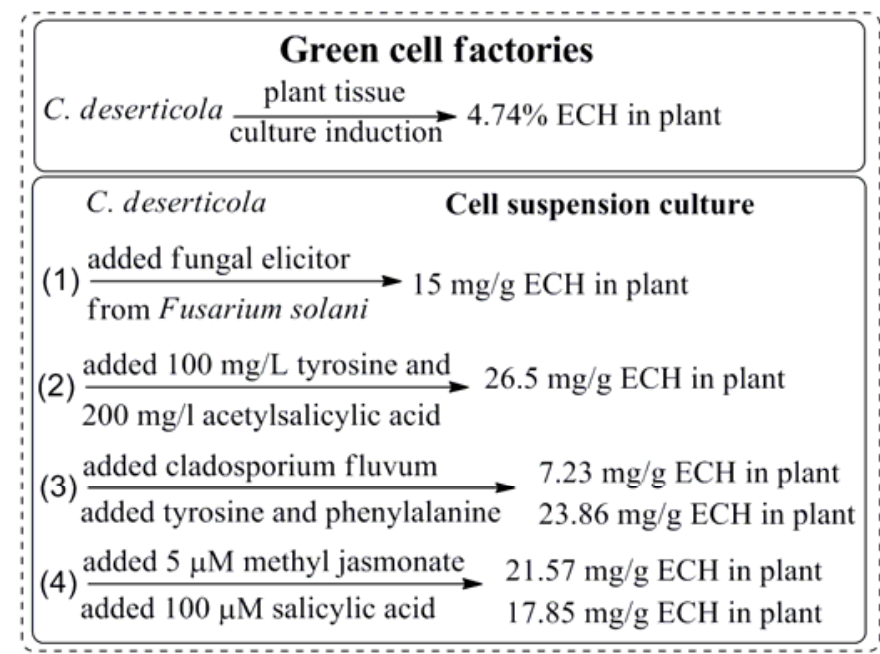

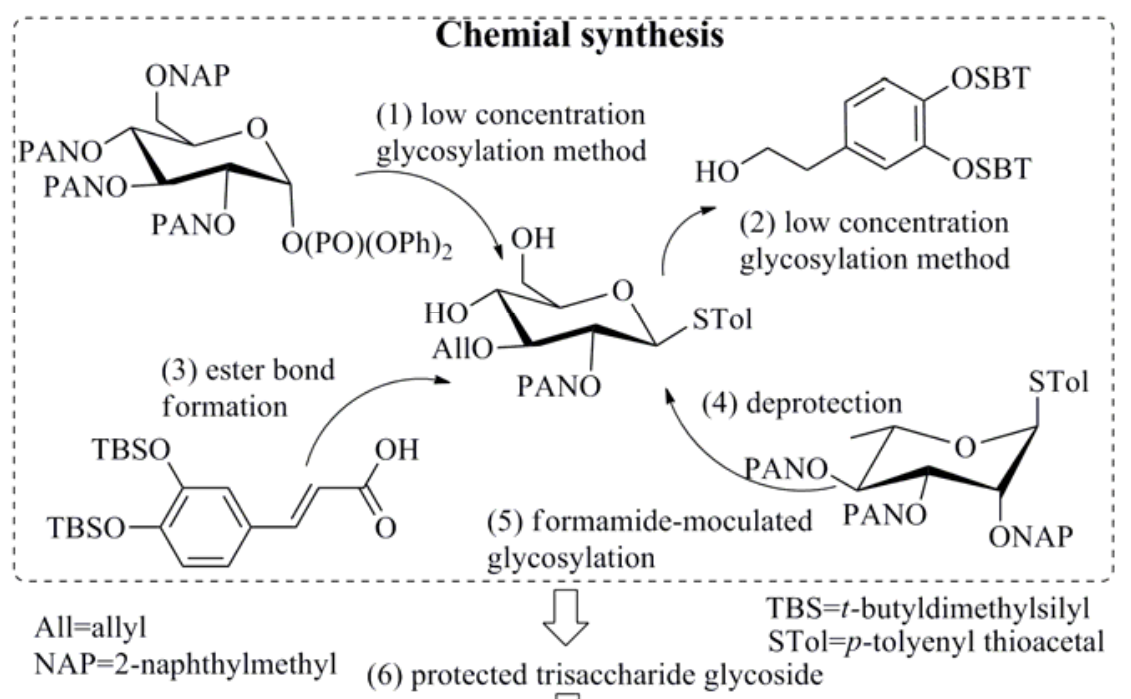

\section{$\sum_{\text {ECH }} 4.5 \%$ overall yield}

Figure 3. Different methods of ECH obtaining.

\section{Pharmacokinetics and Strategy}

Generally, the systemic effects of natural PhGs mainly depend on their bioavailabilities through the gastrointestinal barrier. However, both in vitro and in vivo experimental data appeared to reflect their pitiful fates in the gut, including relatively poor bioavailabilities and rapid rates of excretion [29]. Dozens of studies have shown that the content of PhGs in plant within $\mu \mathrm{g}$, following ingestion, they appeared in the circulation as phase II metabolites, and their plasma levels rarely exceed $\mathrm{nM}$ concentrations [30]. Animal study confirmed that the absolute bioavailability of ECH was only $0.83 \%$ [31], as Table 1 shown, the absorption and elimination of ECH was extremely fast in rats and the serum concentration was very low, and $\mathrm{ECH}$ could not be identified in any human plasma sample at any time after ECH tablet ingestion [32]. The serum concentration-time curves for intragastric and intravenous administration were fitted to one-compartment model and two-compartment model, respectively. The metabolites of ECH in rat feces were identified as acteoside, decaffeoylacteoside, lugrandosie and 3,4-dihydrophenyl ethanol after oral administration [33], and a portion of ECH was transformed into acteoside [34]. Now, to predict the absorption of orally administrated drugs, Caco-2 monolayer is widely used as a model of the human intestinal mucosa. It was shown that $\mathrm{ECH}$ permeated poorly through the Caco-2 monolayers although one potential metabolite, cinnamic 
acid, diffused readily with an apparent permeability of $1 \times 10^{-4} \mathrm{~cm} / \mathrm{s}$. The data implied ECH was not likely to cross the normal intestinal barrier [35-37], but it can through the blood-brain barrier in permanent middle cerebral artery occlusion (MCAO) rats [38]. Furthermore, a recent study estimated the dynamic pharmacokinetic of ECH between Parkinson's disease rat and normal rats showed that the plasma concentrations of ECH in Parkinson's disease rats were higher than that in the normal rats after oral administration. The reasons why the elimination rate of ECH slowed down in Parkinson's disease rats may be as follows: ECH is partially hydrolyzed to aglycone in the body and in the state of pathophysiology, a low activity of certain enzymes induced by 6-hydroxydopamine (6-OHDA) damage might lead to the decreased clearance rate and increased retention time of $\mathrm{ECH}$. Even if ECH was mainly excreted in the urine, the decreased blood circulation of kidney induced by 6-OHDA damage might play an important role in the decreased elimination rate and increased retention time of ECH [39].

Table 1. Pharmacokinetics of ECH with different models.

\begin{tabular}{|c|c|c|}
\hline Dose/Model & Pharmacokinetics Parameters including Metabolites & Ref. \\
\hline $100 \mathrm{mg} / \mathrm{kg}$ p.o./rats & $\begin{array}{c}T_{\max }=15.0 \mathrm{~min}, C_{\max }=612.2 \pm 320.4 \mathrm{ng} / \mathrm{mL} \\
T_{1 / 2}=74.4 \mathrm{~min}, C_{6 \mathrm{~h}}=36.3 \mathrm{ng} / \mathrm{mL} \text {, fit to one-compartment } \\
\text { model, absolute bioavailability was } 0.83 \% .\end{array}$ & {$[31,40]$} \\
\hline $5 \mathrm{mg} / \mathrm{kg}$ i.p./rats & $\begin{array}{c}T_{1 / 2 \alpha}=12.4 \mathrm{~min}, T_{1 / 2 \beta}=41.0 \mathrm{~min}, C_{2 \min }=15598.8 \mathrm{ng} / \mathrm{mL} \\
C_{4 \mathrm{~h}}=143.6 \mathrm{ng} / \mathrm{mL} \text {, fit to two-compartment model. }\end{array}$ & {$[31,40]$} \\
\hline $100 \mathrm{mg} / \mathrm{kg}$ p.o. $/$ rats & $\begin{array}{l}\text { Rat feces: acteoside, decaffeoylacteoside, lugrandosie, } \\
\text { 3,4-dihydrophenyl ethanol. }\end{array}$ & [33] \\
\hline $3 \mathrm{~g} / \mathrm{kg}$ of total PhGs p.o. $/$ rats & $\begin{array}{l}\text { PhGs are mainly metabolized in large intestine, and the } \\
\text { content of ECH fell from } 48 \% \text { to } 16 \% \text {, a portion of which was } \\
\text { transformed into acteoside. }\end{array}$ & [34] \\
\hline $\begin{array}{l}\text { ECH tablet manufactured from } \\
\text { ethanolic liquid extracts of } E . \\
\text { angustifolia and E. purpurea p.o./9 } \\
\text { healthy volunteers }\end{array}$ & $\begin{array}{l}\text { ECH could not be identified in any human plasma } \\
\text { sample at any time. }\end{array}$ & {$[32,36]$} \\
\hline $\begin{array}{l}20 \mathrm{mg} / \mathrm{kg} \text { p.o./Parkinson's } \\
\text { disease and normal rats }\end{array}$ & $\begin{array}{c}T_{1 / 2}=73.9 \mathrm{~min} \text { and } C_{\max }=403.6 \pm 52.3 \mathrm{ng} / \mathrm{mL} \text { in } \\
\text { Parkinson's disease rats, } T_{1 / 2}=121.6 \mathrm{~min} \text { and } \\
C_{\max }=365.2 \pm 46.4 \mathrm{ng} / \mathrm{mL} \text { in normal rats. }\end{array}$ & [39] \\
\hline $50 \mathrm{mg} / \mathrm{kg}$ p.o. $/ \mathrm{MCAO}$ rats & $\begin{array}{c}C_{5 \min }=29.83 \mathrm{ng} / \mathrm{mL}, C_{15 \min }=31.28 \mathrm{ng} / \mathrm{mL} \\
C_{30 \mathrm{~min}}=40.21 \mathrm{ng} / \mathrm{mL}, C_{45 \min }=26.49 \mathrm{ng} / \mathrm{mL}, C_{60 \mathrm{~min}} \\
=21.20 \mathrm{ng} / \mathrm{mL}, C_{90 \min }=14.04 \mathrm{ng} / \mathrm{mL}, C_{120 \mathrm{~min}} \text { blow LOD. }\end{array}$ & [38] \\
\hline $\begin{array}{l}8.4 \pm 1.6 \mu \mathrm{g} / \mathrm{mL} / \mathrm{Caco}-2 \\
\text { monolayers }\end{array}$ & $\begin{array}{l}\text { Permeated poorly, } 0 \% \text { was uptake at } 90 \mathrm{~min} \text {, and the } \\
\text { apparent permeability was zero. }\end{array}$ & {$[35,36]$} \\
\hline $200 \mu \mathrm{M} /$ Caco-2 monolayers & $\begin{array}{l}\text { Passive diffusion, apparent permeability was nearly } \\
\qquad 10^{-7} \mathrm{~cm} / \mathrm{s} .\end{array}$ & [37] \\
\hline
\end{tabular}

MCAO, middle cerebral artery occlusion; LOD, limit of detection; p.o., intragastric administration; i.p., intraperitoneal injection.

\section{Pharmacological Properties and Underlying Mechanisms}

$\mathrm{ECH}$ was proved possessing kinds of pharmacological activities since it was found sixty years ago, the data of this review were mainly gathered by consulting the database of PubMed, Springer, Elsevier, and Scholar in the last 30 years. Among the broad range of therapeutic applications of $\mathrm{ECH}$, its neuroprotective bioactive has attracted the more attention of pharmaceutical scientists than the others. Dozens of reports have discovered that ECH was effective in Parkinson's and Alzheimer's diseases by using both animal experiments and cell lines tests, which were shown in Table 2. Besides the neuroprotective action, the cardioactive property, anti-inflammatory activity, antioxidant and anti-osteoporotic activities as well as other pharmacological potentials of ECH were 
presented in Tables 3-7, respectively. The data of Table 2 and Figure 4 showed that ECH could prevent the progress of neurodegeneration in Parkinson's and Alzheimer's diseases. Several Parkinson's or Alzheimer's animal models induced by 6-OHDA, 1-methyl-4-phenyl-1,2,3,6-tetrahydropyridine (MPTP), D-galactose and $\beta$-amyloid $A \beta-(25-35)$ as well as cerebral ischemia rats were used to estimate the neuroprotective effects of ECH. PC12 and neuroblastoma SH-SY5Y cell lines were employed to discover the related mechanisms, which were related to the mitogen-activated protein kinase (MAPK), NF-kappa B, caspase 3 and 8 as well as reactive oxygen species (ROS)/activating transcription factor 3 (ATF3)/C/EBP-homologous protein (CHOP) pathways, as Figure 4 showed. However, most of the above data were obtained by using cells or animals, the reliable clinical trials were limited, large-scale evidence-based human clinical trials with specific neuroprotective therapeutic settings are necessary. The same problems have been found by applying other evaluation methods of the different pharmacological properties.

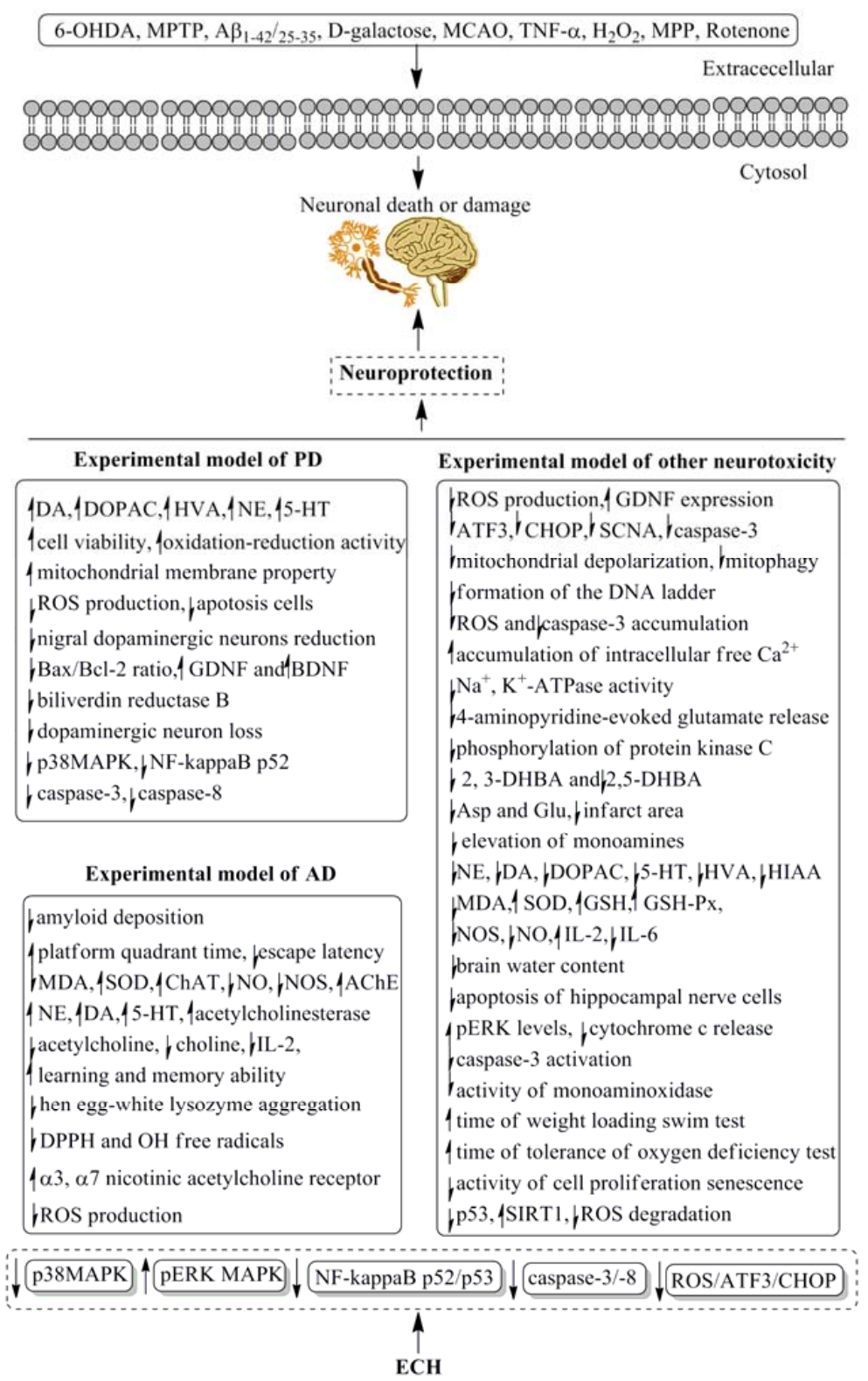

Figure 4. The underlying mechanism of neuroprotective of ECH. AD, Alzheimer's disease; PD, Parkinson's disease. 
Table 2. Neuroprotective activity of ECH in selected models.

\begin{tabular}{|c|c|c|c|}
\hline Models & Dosage & Mechanism & Ref \\
\hline $\begin{array}{l}\text { 6-OHDA-induced } \\
\text { Parkinson's disease in rats }\end{array}$ & 10,20 and $40 \mathrm{mg} / \mathrm{kg}$ for 4 weeks, i.p. & $\begin{array}{l}\text { Increased the striatal and hippocampus extracellular fluid of DA, DOPAC, } \\
\text { HVA, NE, and 5-HT levels. }\end{array}$ & {$[41]$} \\
\hline $\begin{array}{l}\text { 6-OHDA-induced } \\
\text { Parkinson's disease in rats }\end{array}$ & 3,5 and $7 \mathrm{mg} / \mathrm{kg}$ for 7 days, i.p. & Prevented the decreased of the striatal extracellular levels of DA, DOPAC and HVA. & {$[42]$} \\
\hline $\begin{array}{l}\text { 6-OHDA-induced } \\
\text { neurotoxicity in rats }\end{array}$ & 3,5 and $7 \mathrm{mg} / \mathrm{kg}$ for 7 days, i.p. & $\begin{array}{l}\text { Prevented the decreased of the extracellular levels of DA, DOPAC and HVA, elevated the } \\
\text { concentrations of DA, DOPAC and HVA in the right striatum of awake, freely-moving rats. }\end{array}$ & {$[43]$} \\
\hline $\begin{array}{l}\text { 6-OHDA-induced } \\
\text { neurotoxicity in PC12 cells }\end{array}$ & $0.1,1$ and $10 \mu \mathrm{M}$ & $\begin{array}{l}\text { Significantly enhanced cell viability, oxidation-reduction activity and mitochondrial } \\
\text { membrane potential, reduced ROS production, as well as inhibited } \\
\text { mitochondria-mediated apoptosis. }\end{array}$ & {$[44]$} \\
\hline $\begin{array}{l}\text { MPTP-induced neurotoxicity } \\
\text { in mice }\end{array}$ & $30 \mathrm{mg} / \mathrm{kg}$ for 14 days, p.o. & $\begin{array}{l}\text { Suppressed the reduction of nigral dopaminergic neurons, striatal fibers, DA and DA } \\
\text { transporter, prevented the apoptosis cells and Bax/Bcl-2 ratio of mRNA and protein, } \\
\text { increased the expression level of GDNF and BDNF mRNA and protein, } \\
\text { and improved the gait disorder. }\end{array}$ & {$[45]$} \\
\hline $\begin{array}{l}\text { MPTP-induced Parkinson's } \\
\text { disease in C57BL/6 mice }\end{array}$ & $20 \mathrm{mg} / \mathrm{kg}$ for 14 days, p.o. & $\begin{array}{l}\text { Protected the C57BL/ } 6 \text { mice against MPTP-induced behavioral default, increased the } \\
\text { number of spontaneous movement and latent period of mice on the rotating rod., } \\
\text { and decreased the level of protein biliverdin reductase B. }\end{array}$ & {$[46]$} \\
\hline $\begin{array}{l}\text { MPTP-induced Parkinson's } \\
\text { disease in C57BL/6 mice }\end{array}$ & $30 \mathrm{mg} / \mathrm{kg}$ for 14 days, p.o. & $\begin{array}{l}\text { Suppressed the dopaminergic neuron loss, maintained dopamine and dopamine metabolite } \\
\text { content, inhibited the activation of microglia and astrocytes in the substantia nigra; } \\
\text { downregulated the level of p38MAPK and the NF-kappaB p52 subunit. }\end{array}$ & {$[47]$} \\
\hline $\begin{array}{l}\text { MPTP-induced Parkinson's } \\
\text { disease in mice }\end{array}$ & 5 and $20 \mathrm{mg} / \mathrm{kg}$ for 15 days, p.o. & $\begin{array}{c}\text { Reduced behavioral deficits and cell death, increased striatal DA, DA metabolite levels and } \\
\text { tyrosine hydroxylase expression; reduced caspase- } 3 \text { and caspase- } 8 \text { activation in } \\
\text { MPP-induced apoptosis in cerebellar granule neurons. }\end{array}$ & {$[48]$} \\
\hline $\begin{array}{l}\text { MPTP-induced neurotoxicity } \\
\text { in SH-SY5Y cells }\end{array}$ & 10,20 and $40 \mu \mathrm{g} / \mathrm{mL}$ & $\begin{array}{c}\text { Improved cell survival, suppressed the generation of ROS and the expression of apoptotic } \\
\text { genes (ATF3, CHOP, and SCNA), and decreased the caspase-3 activity in a dose-dependent } \\
\text { manner; restored the GDNF expression, improved dopaminergic neuron survival and } \\
\text { protected these neurons against apoptosis; protected apoptosis } \\
\text { through ROS/ATF3/CHOP pathway. }\end{array}$ & {$[49]$} \\
\hline
\end{tabular}


Table 2. Cont.

\begin{tabular}{|c|c|c|c|}
\hline Models & Dosage & Mechanism & Ref. \\
\hline $\begin{array}{c}\text { A } \beta-(1-42) \text {-induced } \\
\text { Alzheimer's disease in rats }\end{array}$ & 25 and $50 \mathrm{mg} / \mathrm{kg}$ for 15 days, p.o. & $\begin{array}{c}\text { Ameliorated the cognitive deficits, decreased amyloid deposition, reversed cholinergic and } \\
\text { hippocampal dopaminergic dysfunction. }\end{array}$ & [50] \\
\hline $\begin{array}{l}\text { D-galactose coupled with } \\
\text { A } \beta-(25-35) \text {-induced } \\
\text { Alzheimer's disease in rats }\end{array}$ & 10,20 and $40 \mathrm{mg} / \mathrm{kg}$ for 4 weeks, i.p. & $\begin{array}{l}\text { Extended the platform quadrant time, shortened the escape latency, alleviated the learning } \\
\text { and memory impairment, and improved the concentrations of NE, DA, 5-HT in the } \\
\text { hippocampus and cerebral cortex. }\end{array}$ & [51] \\
\hline $\begin{array}{l}\text { Occluding the bilateral } \\
\text { common carotid arteries } \\
\text { induced Vascular } \\
\text { dementia in rats }\end{array}$ & 15,30 and $45 \mathrm{mg} / \mathrm{kg}$ for 4 weeks, i.p. & $\begin{array}{l}\text { Decreased the content of MDA and increased the activities of SOD, ChAT, and AChE in the } \\
\text { hippocampus and cerebral cortex. }\end{array}$ & [52] \\
\hline $\begin{array}{l}\text { D-galactose coupled with } \\
\text { A } \beta \text {-(25-35)-induced } \\
\text { Alzheimer's disease in rats }\end{array}$ & 10,20 and $40 \mathrm{mg} / \mathrm{kg}$ for 4 weeks, i.p. & $\begin{array}{l}\text { Decreased the content of MDA, increased the activity of SOD, reduced the release of } \mathrm{NO} \text { and } \\
\text { NOS in the hippocampus and cortex brain tissue. }\end{array}$ & [53] \\
\hline $\begin{array}{l}\text { Rapid aging dementia in } \\
\text { sam-p/8 mice }\end{array}$ & $50 \mathrm{mg} / \mathrm{kg}$ for 30 days, p.o. & $\begin{array}{l}\text { Increased the learning and memory ability, reduced the levels of acetylcholine and IL-2, } \\
\text { increased the total anti-oxidative ability. }\end{array}$ & [54] \\
\hline $\begin{array}{l}\text { Permanent bilateral common } \\
\text { carotid artery occlusion } \\
\text { induced Vascular } \\
\text { dementia in rats }\end{array}$ & 15,30 and $45 \mathrm{mg} / \mathrm{kg}$ for 4 weeks, i.p. & $\begin{array}{l}\text { Increased the content of acetylcholine, enhanced the activity of acetylcholinesterase, reduced } \\
\text { the content of choline extracellular of hippocampus and striatum. }\end{array}$ & [55] \\
\hline $\begin{array}{l}\mathrm{A} \beta-(25-35) \text {-induced } \\
\text { neurotoxicity in PC12 cells }\end{array}$ & 100,300 and $500 \mu \mathrm{M}$ & $\begin{array}{c}\text { Inhibited hen egg-white lysozyme aggregation occurred in different fiber-forming stages, } \\
\text { scavenged the DPPH and OH free radicals, increased viability of PC12 cell line, } \\
\text { and suppressed the increase in intracellular ROS. }\end{array}$ & [56] \\
\hline $\begin{array}{l}\text { A } \beta \text {-(25-35)-induced } \\
\text { neurotoxicity in } \\
\text { SH-SY5Y cells }\end{array}$ & $80 \mu \mathrm{M}$ & $\begin{array}{l}\text { Stimulated the increase of } \alpha 3 \text { and } \alpha 7 \text { nicotinic acetylcholine receptor subunit } \\
\text { proteins and cell viability. }\end{array}$ & [57] \\
\hline $\begin{array}{l}\text { MPP induced neurotoxicity in } \\
\text { SH-SY5Y cells }\end{array}$ & 5,10 and $20 \mu \mathrm{g} / 1$ & $\begin{array}{l}\text { Suppressed the mitochondrial depolarization, mitophagy and cell apoptosis, exhibited } \\
\text { protective effects on mitochondrial function and cell apoptosis. }\end{array}$ & [58] \\
\hline $\begin{array}{l}\text { TNF- } \alpha \text { induced neurotoxicity } \\
\text { in SHSY5Y cells }\end{array}$ & 1,10 and $100 \mu \mathrm{g} / \mathrm{mL}$ & $\begin{array}{l}\text { Reduced formation of the DNA ladder, prevented the accumulation of ROS and caspase- } 3 \text {, } \\
\text { reconverted the potential of mitochondarial membrane, and decreased the percentage of } \\
\text { apoptosis/necrosis neurons. }\end{array}$ & [59] \\
\hline
\end{tabular}


Table 2. Cont.

\begin{tabular}{|c|c|c|c|}
\hline Models & Dosage & Mechanism & Ref. \\
\hline $\begin{array}{l}\text { TNF- } \alpha \text { induced neurotoxicity } \\
\text { in SHSY5Y cells }\end{array}$ & 1,10 and $100 \mu \mathrm{g} / \mathrm{mL}$ & $\begin{array}{l}\text { Prevented the accumulation of ROS, maintained the function of mitochondria, inhibited the } \\
\text { activity of caspase- } 3 \text { activity and increased the expression of the antiapoptotic protein Bcl2. }\end{array}$ & [60] \\
\hline $\begin{array}{l}\mathrm{H}_{2} \mathrm{O}_{2} \text { induced neurotoxicity } \\
\text { in SH-SY5Y cells }\end{array}$ & $50 \mu \mathrm{M}$ & Protected SH-SY5Y cells against $\mathrm{H}_{2} \mathrm{O}_{2}$ induced oxidative injury. & [61] \\
\hline $\begin{array}{l}\mathrm{H}_{2} \mathrm{O}_{2} \text { induced neurotoxicity } \\
\text { in PC12 cells }\end{array}$ & 5 and $10 \mu \mathrm{g} / \mathrm{mL}$ & $\begin{array}{l}\text { Increased cell viability, decreased the apoptotic ratio, inhibited the formation of } \mathrm{ROS} \text { and } \\
\text { accumulation of intracellular free } \mathrm{Ca}^{2+} \text {, elevated the mitochondrial membrane potential in } \\
\mathrm{H}_{2} \mathrm{O}_{2} \text { induced PC12 cells, downregulated Bax protein expression and upregulated } \mathrm{Bcl}-2 \\
\text { protein expression, and prevented an } \mathrm{H}_{2} \mathrm{O}_{2} \text { induced increase of the Bax/Bcl-2 ratio. }\end{array}$ & [62] \\
\hline $\begin{array}{l}\mathrm{H}_{2} \mathrm{O}_{2} \text { induced neurotoxicity } \\
\text { in PC12 cells }\end{array}$ & $10 \mu \mathrm{M}$ & $\begin{array}{l}\text { Increased cell viability and decreased the necrotic ratio, inhibited the formation of NO, } \\
\text { down-regulated p65 and iNOS mRNA expressions. }\end{array}$ & [63] \\
\hline $\begin{array}{l}\mathrm{H}_{2} \mathrm{O}_{2} \text { induced neurotoxicity } \\
\text { in PC12 cells }\end{array}$ & 5 and $10 \mu \mathrm{g} / \mathrm{mL}$ & $\begin{array}{l}\text { Increased cell viability and } \mathrm{Na}^{+}, \mathrm{K}^{+} \text {-ATPase activities as well as mitochondrial membrane } \\
\text { bioactive, down-regulated the expressions of p53 mRNA and up-regulated the expressions of } \\
\text { Bcl-2 mRNA. }\end{array}$ & [64] \\
\hline $\begin{array}{l}\mathrm{H}_{2} \mathrm{O}_{2} \text { induced neurotoxicity } \\
\text { in PC12 cells }\end{array}$ & $1,5,10,30$, and $50 \mu \mathrm{M}$ & $\begin{array}{l}\text { Inhibited } \mathrm{Ca}^{2+} \text { dependent } 4 \text {-aminopyridine-evoked glutamate release, reduced the } \\
\text { 4-aminopyridine-evoked increase in cytoplasmic free } \mathrm{Ca}^{2+} \text { concentration, decreased the } \\
\text { phosphorylation of protein kinase C. }\end{array}$ & [65] \\
\hline $\begin{array}{l}\text { Permanent MCAO-induced } \\
\text { neurotoxicity in rats }\end{array}$ & 15 and $30 \mathrm{mg} / \mathrm{kg}$ for 7 days, i.p. & Prevented the elevation of 2, 3-DHBA and 2,5-DHBA. & [66] \\
\hline $\begin{array}{l}\text { Permanent MCAO-induced } \\
\text { neurotoxicity in rats }\end{array}$ & 20 and $40 \mathrm{mg} / \mathrm{kg}$ for 7 days, i.p. & Decreased the levels of Asp and Glu, reduced the infarct area. & {$[67]$} \\
\hline $\begin{array}{l}\text { Permanent MCAO-induced } \\
\text { neurotoxicity in rats }\end{array}$ & 15 and $30 \mathrm{mg} / \mathrm{kg}$ for 7 days, i.p. & Prevented the elevation of monoamines, NE, DA, DOPAC, 5-HT and HIAA. & [68] \\
\hline $\begin{array}{l}\text { Permanent MCAO-induced } \\
\text { neurotoxicity in rats }\end{array}$ & 15 and $30 \mathrm{mg} / \mathrm{kg}$ for 7 days, i.p. & Decreased the content of MDA, and increased the activities of SOD and GSH. & [69] \\
\hline $\begin{array}{l}\text { Permanent MCAO-induced } \\
\text { neurotoxicity in rats }\end{array}$ & 25 and $50 \mathrm{mg} / \mathrm{kg}$ for 7 days, i.p. & $\begin{array}{l}\text { Improved neurological deficit, reduced brain water content and the apoptosis of } \\
\text { hippocampal nerve cells. }\end{array}$ & [70] \\
\hline $\begin{array}{l}\text { Permanent MCAO-induced } \\
\text { neurotoxicity in rats }\end{array}$ & 15 and $30 \mathrm{mg} / \mathrm{kg}$ for 7 days, i.p. & Attenuated the increased of NE, DA, DOPAC, 5-HT and HIAA. & [71] \\
\hline $\begin{array}{l}\text { Permanent MCAO-induced } \\
\text { neurotoxicity in rats }\end{array}$ & 15 and $30 \mathrm{mg} / \mathrm{kg}$ for 7 days, i.p. & Prevented the extracellular levels of NE, DA, DOPAC, HIAA, HVA and 5-HT. & [72] \\
\hline
\end{tabular}


Table 2. Cont.

\begin{tabular}{|c|c|c|c|}
\hline Models & Dosage & Mechanism & Ref. \\
\hline $\begin{array}{l}\text { Rotenone-induced } \\
\text { Parkinson's disease in rats }\end{array}$ & 20,40 and $80 \mathrm{mg} / \mathrm{kg}$ for 4 weeks, i.p. & $\begin{array}{l}\text { Suppressed the neurological disability and the loss of dopaminergic neurons in substantia } \\
\text { nigra, increased DA concentrations in striatum, no effect on liver and kidney damage. }\end{array}$ & [73] \\
\hline $\begin{array}{l}\text { Rotenone-induced injury in } \\
\text { SHSY5Y, Hela and } \\
\text { HEK293T cells }\end{array}$ & 5,10 and $20 \mu \mathrm{g} / \mathrm{mL}$ & $\begin{array}{l}\text { Protected cells over-expressed with TrkA or TrkB against rotenone injury, elevated the pERK } \\
\text { levels and inhibited cytochrome c release and caspase- } 3 \text { activation. }\end{array}$ & [74] \\
\hline $\begin{array}{l}\text { Permanent MCAO-induced } \\
\text { neurotoxicity in rats }\end{array}$ & 10,20 and $40 \mathrm{mg} / \mathrm{kg}$ for 4 weeks, i.p. & $\begin{array}{l}\text { Increased the content of GSH and activity of GSH-Px, decreased the activity of NOS; } \\
\text { arranged the rat tissue structure of hippocampal CAI area in order. }\end{array}$ & [75] \\
\hline $\begin{array}{l}\text { D-galactose induced subacute } \\
\text { aging in mice }\end{array}$ & $50 \mathrm{mg} / \mathrm{kg}$ for 6 weeks, p.o. & $\begin{array}{l}\text { Scavenged the free radicals of } \mathrm{OH}, \mathrm{O}_{2} \text { and } \mathrm{L} \text {, repaired the damages, enhanced the activities } \\
\text { of GSH-PX and SOD, reduced the content of MDA, and decreased the activity of } \\
\text { monoaminoxidase thus delay the aging process. }\end{array}$ & [76] \\
\hline $\begin{array}{l}\text { D-galactose induced subacute } \\
\text { aging in mice }\end{array}$ & 20,40 and $60 \mathrm{mg} / \mathrm{kg}$ for 8 weeks, p.o. & $\begin{array}{l}\text { Reduced the content of IL- } 6 \text { and MDA, increased the content of IL- } 2 \text { and NO, enhanced the } \\
\text { immune function and activity of SOD in brain tissue. }\end{array}$ & [77] \\
\hline $\begin{array}{l}\text { D-galactose induced subacute } \\
\text { aging in mice. }\end{array}$ & 20,40 and $60 \mathrm{mg} / \mathrm{kg}$ for 8 weeks, p.o. & $\begin{array}{l}\text { Increased the content of IL-2, reduced the content of IL-6, MDA and mitochondrial DNA, } \\
\text { improved phagocytosis of peritoneal macrophages and transformation of } \\
\text { spleen lymphocytes. }\end{array}$ & [78] \\
\hline $\begin{array}{l}\text { D-galactose induced subacute } \\
\text { aging in mice. }\end{array}$ & 10,20 and $40 \mathrm{mg} / \mathrm{kg}$ for 8 weeks, p.o. & $\begin{array}{l}\text { Prolonged the time of weight loading swim test and tolerance of oxygen deficiency test, } \\
\text { increased the activity of SOD and the level of IL-2, reduced the content of MDA. }\end{array}$ & [79] \\
\hline $\begin{array}{l}\text { Replicative induced } \\
\text { senescence and } \mathrm{H}_{2} \mathrm{O}_{2} \\
\text { induced neurotoxicity in } \\
\text { MRC-5 cells }\end{array}$ & 20,50 and $100 \mu \mathrm{M}$ & Down-regulated the expression of p53 and up-regulated the expression level of SIRT1. & [80] \\
\hline $\begin{array}{l}\text { Replicative induced } \\
\text { senescence and } \mathrm{H}_{2} \mathrm{O}_{2} \\
\text { induced neurotoxicity in } \\
\text { MRC-5 cells }\end{array}$ & $1,20,50$ and $100 \mu \mathrm{M}$ & $\begin{array}{l}\text { Retarded the activity of cell proliferation senescence, triggered cells in the G1 phase to enter } \\
\text { the S phase and G2 phase, improved the ROS degradation, and protected cells } \\
\text { from DNA damage. }\end{array}$ & [81] \\
\hline
\end{tabular}


Table 3. Cardioactive property of ECH in selected models.

\begin{tabular}{|c|c|c|c|}
\hline Models & Dosage & Activity/Mechanism & Refs \\
\hline $\begin{array}{l}5 \text {-FU induced bone } \\
\text { marrow depression mice }\end{array}$ & $15 \mathrm{mg} / \mathrm{kg}$ for 12 days, p.o. & $\begin{array}{l}\text { Stimulated the proliferation ability of bone } \\
\text { marrow cells. }\end{array}$ & [82] \\
\hline Bone marrow cells & $0.1,1,10,25$ and $50 \mu \mathrm{M}$ & $\begin{array}{l}\text { Increased the number of total } \\
\text { hematopoietic progenitor cells and } \\
\text { granulocyte macrophage progenitor cells to } \\
\text { healthy control mice level. }\end{array}$ & [82] \\
\hline $\begin{array}{l}\text { 5-FU induced bone } \\
\text { marrow depression mice }\end{array}$ & $15 \mathrm{mg} / \mathrm{kg} /$ day for 12 days, p.o. & $\begin{array}{l}\text { Improved the hematopoietic function of } \\
\text { bone marrow, activated the PI3K } \\
\text { signaling pathway. }\end{array}$ & [83] \\
\hline $\begin{array}{l}\text { Hypoxia-induced } \\
\text { proliferation of rat } \\
\text { pulmonary artery } \\
\text { smooth muscle cells }\end{array}$ & $0.35-0.4 \mathrm{mM}$ of ECH & $\begin{array}{l}\text { Stimulated the apoptosis of pulmonary } \\
\text { artery smooth muscle cells, enhanced the } \\
\text { protein and gene expression of caspase- } 3 \text {, } \\
\text { Bax and Fas, decreased the expressions of } \\
\text { Bcl-2 and hypoxia-inducible factor- } 1 \alpha \text {. }\end{array}$ & [84] \\
\hline $\begin{array}{l}\text { TNF- } \alpha \text { induced } \\
\text { atherosclerosis of human } \\
\text { umbilical vascular } \\
\text { endothelial cells }\end{array}$ & 40,80 and $100 \mathrm{mg} / \mathrm{L}$ & $\begin{array}{l}\text { Increased the survival of human umbilical } \\
\text { vascular endothelial cells, reduced the } \\
\text { secretion of lactate dehydrogenase, MDA, } \\
\text { intercellular adhesion molecule- } 1 \text { and the } \\
\text { production of intracellular reactive oxygen. }\end{array}$ & [85] \\
\hline $\begin{array}{l}\text { Phenylephrine and } \mathrm{KCl} \\
\text { induced contracted of } \\
\text { the isolated rat thoracic } \\
\text { aortic ring }\end{array}$ & $30-300 \mu \mathrm{M}$ & $\begin{array}{l}\text { Relaxed the endothelium-intact rings, } \\
\text { enhanced the cyclic guanosine } \\
\text { monophosphate production in aortic rings } \\
\text { through NO-cyclic guanosine } \\
\text { monophosphate pathway. }\end{array}$ & [86] \\
\hline $\begin{array}{l}\text { Noradrenaline induced } \\
\text { contractions in isolated } \\
\text { rat aortic strip }\end{array}$ & $10-100 \mu \mathrm{M}$ & $\begin{array}{l}\text { Methanolic extract from the dried stems of } \\
\text { Cistanche tubulosa inhibited the contractions, } \\
\text { and ECH was responsible for this bioactive. }\end{array}$ & [87] \\
\hline
\end{tabular}

5-FU, 5-fluorouracil; PI3K, phosphatidylinositol 3-kinase.

One of the traditional uses of Cistanche deserticola was for treatment of irritable bowel syndrome disease, and $\mathrm{ECH}$ was the main bioactive ingredients in this herbal responsible for the activity. To date, dozens of in vivo studies demonstrated the anti-inflammatory property of $\mathrm{ECH}$, the data of Table 4 showed that ECH could suppress the acute colitis in mice induced by dextran sulphate sodium [88], attenuate acute hepatotoxicity in rats induced by D-galactosamine/lipopolysaccharide [89] and carbon tetrachloride $\left(\mathrm{CCl}_{4}\right)$ [90], increase hyaluronan levels and decrease wound contraction for wound healing, modulate inflammatory markers including transforming growth factor (TGF)- $\beta 1$, NO, alanine aminotransferase (ALT), myeloperoxidase, inflammatory cytokines, and etc.; however, the molecular mechanisms of the anti-inflammatory of $\mathrm{ECH}$ were limited, which were only related to the expressions of TGF- $\beta 1$, capase- 3 and TNF- $\alpha$.

Table 4. Anti-inflammatory property of ECH in selected models.

\begin{tabular}{|c|c|c|c|}
\hline Models & Dosage/Concentration & Mechanism & Refs \\
\hline $\begin{array}{c}\mathrm{H}_{2} \mathrm{O}_{2} \text { or pro-inflammatory } \\
\text { cytokines induced injury on } \\
\mathrm{C} 3 \mathrm{H} / \mathrm{HeJ} \text { mice intestinal epithelial } \\
\text { MODE-K cells }\end{array}$ & $6.25-100 \mu \mathrm{g} / \mathrm{mL}$ & $\begin{array}{l}\text { Stimulated cell proliferation, improved mucosal } \\
\text { tissue repair, enhanced cell survival by reducing cell } \\
\text { apoptosis, up-regulated TGF- } \beta 1 \text { expression. }\end{array}$ & [91] \\
\hline $\begin{array}{l}\text { Lipopolysaccharide stimulated } \\
\text { murine J774.1 cells, } \\
\text { lipopolysaccharide/interferon-g } \\
\text { stimulated mouse peritoneal } \\
\text { exudate macrophages }\end{array}$ & $2-200 \mu \mathrm{M}$ & $\begin{array}{l}\text { Inhibited and reduced nitrite accumulation and } \\
\text { scavenged the nitrite generated from } \\
\text { 1-propanamine-3-hydroxy-2- } \\
\text { nitroso-1-propylhydrazino. }\end{array}$ & [92] \\
\hline
\end{tabular}


Table 4. Cont.

\begin{tabular}{|c|c|c|c|}
\hline Models & Dosage/Concentration & Mechanism & Refs \\
\hline $\begin{array}{l}\text { Dextran sulphate sodium-induced } \\
\text { acute colitis in C57BL/6J mice, } \\
\mathrm{C} 3 \mathrm{H} / \mathrm{HeJ} \text { mice intestinal epithelial } \\
\text { MODE-K cells }\end{array}$ & $\begin{array}{l}0.12-20 \mathrm{mg} / \mathrm{kg} / \text { day } \\
\quad \text { for } 7 \text { days, p.o. }\end{array}$ & $\begin{array}{l}\text { Suppressed the development of acute colitis, } \\
\text { prevented colonic damage, protected intestinal } \\
\text { epithelium from inflammatory injury, up-regulated the } \\
\text { expression of TGF- } \beta 1 \text {, and increased the number of } \\
\text { Ki } 67^{+} \text {proliferating cells. }\end{array}$ & [88] \\
\hline $\begin{array}{l}\text { SD rats were abraded to generate } \\
\text { erythema and cicatrization }\end{array}$ & $0.4 \mathrm{mg} / \mathrm{mL}$, topical & $\begin{array}{l}\text { Decreased the edematous process, increased } \\
\text { hyaluronan levels and less wound contraction. }\end{array}$ & [93] \\
\hline $\begin{array}{l}\text { Removed vocal fold lamina propria } \\
\text { to generate injury in pigs }\end{array}$ & $\begin{array}{l}3-12 \mathrm{mg} / \mathrm{mL} \text { for } \\
15 \text { days, topical }\end{array}$ & $\begin{array}{l}\text { Improved the phonation threshold pressure and the } \\
\text { vocal economy, maintained a stable hyaluronan and } \\
\text { collagen content. }\end{array}$ & [94] \\
\hline $\begin{array}{l}\text { D-galactosamine/lipopolysaccharide- } \\
\text { induced acute liver injury in mice } \\
\text { and primary cultured } \\
\text { mouse hepatocytes }\end{array}$ & $\begin{array}{l}\text { 25-100 mg/kg, p.o. } \\
\text { 3-100 } \mu \mathrm{g} / \mathrm{mL}\end{array}$ & $\begin{array}{l}\text { Inhibited the increase in aspartate aminotransaminase } \\
\text { and alanine aminotransaminase, reduced the } \\
\text { sensitivity of hepatocytes to TNF- } \alpha \text {, inhibited the } \\
\text { death of hepatocytes with } \mathrm{IC}_{50} \text { was } 10.2 \mu \mathrm{M} \text {. }\end{array}$ & [89] \\
\hline $\begin{array}{l}\mathrm{CCl}_{4} \text {-induced liver injury and } \\
\text { oxidative stress in rats }\end{array}$ & 50 mg/kg, i.p. & $\begin{array}{l}\text { Reduced the serum ALT, AST, aspartate } \\
\text { aminotransferase, capase- } 3 \text { and TNF- } \alpha \text { levels and } \\
\text { hepatic MDA content as well as ROS production. }\end{array}$ & [90] \\
\hline $\begin{array}{l}\mathrm{CCl}_{4} \text {-induced liver injury and } \\
\text { oxidative stress in rats }\end{array}$ & 50 mg/kg, i.p. & $\begin{array}{l}\text { Decreased ALT and AST levels, reduced the number of } \\
\text { apoptotic hepatocytes and hepatic MDA content, } \\
\text { increased hepatic SOD and GSH activities. }\end{array}$ & [96] \\
\hline
\end{tabular}

It was worth mentioning that, to date, numerous in vitro and in vivo studies have demonstrated the strong antioxidant property of ECH (Table 5). In DPPH assay, the $\mathrm{EC}_{50}$ of ECH was $6.6 \mu \mathrm{M}$ which was 9.5-fold than Trolox; on xanthine/xanthine oxidase generated superoxide anion radical test, the $\mathrm{IC}_{50}$ of $\mathrm{ECH}$ was $2.74 \mu \mathrm{M}$ than tocopherol, and etc. [98-101]. In vivo experiments, $\mathrm{ECH}$ could prompt the ability of anti-oxication, anti-fatigue and anti-stress in vascular dementia rats or subacute aging mice model, and the indirect antioxidant activities of ECH due to the induction or/and activation of major endogenous antioxidant enzymes and inactivation of pro-oxidant enzymes. In addition, the molecular mechanisms of this activity showed that ECH reduced nuclear protein levels of transcription regulator protein $\mathrm{BACH} 1$, enhanced heme oxygenase $1 \mathrm{mRNA}$ levels, down-regulated expression of p53, up-regulated the SIRT1 [102]. Furthermore, the structure-activity relationship of antioxidant property of $\mathrm{ECH}$ was also estimated. It was believed that the inhibitory oxidative hemolysis activity of $\mathrm{ECH}$ was related to the number of phenolic hydroxy groups. $\mathrm{ECH}$, possessing four phenolic hydroxy groups, exhibited stronger antioxidant activities than cistanoside $\mathrm{D}$ possessing only two phenolic hydroxy groups, and compound permethylacteoside with no phenolic hydroxy group inhibited oxidative hemolysis weakly $[103,104]$. 
Table 5. Anti-oxidative property of ECH in selected models.

\begin{tabular}{|c|c|c|}
\hline Models & Activity & Refs \\
\hline DPPH radical scavenging activity & $\mathrm{EC}_{50}=6.6 \mu \mathrm{M}$ & [98] \\
\hline ABTS radical cation assay & $\begin{array}{l}\text { Scavenging capacity was ranged from } 1.13 \% \\
\text { to } 4.45 \% \text { ( } \% \text { ascorbic acid by weight) }\end{array}$ & [99] \\
\hline $\begin{array}{l}\text { Hydroxyl radical generated by the xanthine/ } \\
\text { xanthine oxidase } / \mathrm{Fe}^{2+} / \mathrm{EDTA} \text { system }\end{array}$ & $\begin{array}{l}\text { Reaction between hydroxyl radical and } \\
\text { ECH was } 0.97 \times 10^{1 \circ} \mathrm{L} / \mathrm{mol} / \mathrm{s} \text {. }\end{array}$ & [100] \\
\hline Peroxynitrite radical scavenging activity & $\begin{array}{l}\text { 9.5-fold total oxidant scavenging capacity } \\
\text { of Trolox }\end{array}$ & [101] \\
\hline $\begin{array}{l}\text { Superoxide anion }\left(\mathrm{O}^{2-} .\right) \text { radical scavenging activity } \\
\text { generated by xanthine/xanthine oxidase }\end{array}$ & $\mathrm{IC}_{50}=2.74 \mu \mathrm{M}$, stronger than $\alpha$ tocopherol & [105] \\
\hline $\begin{array}{l}\text { Inhibition of lipid peroxidation induced by ascorbic } \\
\text { acid } / \mathrm{Fe}^{2+} \text { and adenosine diphosphate/nicotinamide } \\
\text { adenine dinucleotide phosphate } / \mathrm{Fe}^{3+}\end{array}$ & $\begin{array}{l}\text { Stronger than } \alpha \text { tocopherol or caffeic acid } \\
\qquad(p<0.05)\end{array}$ & [106] \\
\hline $\begin{array}{l}\text { Reduced the antioxidant response element of BACH1 } \\
\text { in } \mathrm{HaCaT} \text { cells }\end{array}$ & $\begin{array}{c}\text { Enhanced heme oxygenase } 1 \text { mRNA } \\
\text { levels by } 40 \text {-fold in } 72 \mathrm{~h} \text { and cytoplasmic } \\
\text { heme oxygenase } 1 \text { protein levels were } \\
\text { also increased }\end{array}$ & [107] \\
\hline $\begin{array}{l}\text { Oxygen radicals (superoxide anion and hydroxyl } \\
\text { radical), generated by the xanthine/xanthine } \\
\text { oxidase/Fe } \mathrm{Fe}^{2+} / \text { EDTA system, induced degradation of } \\
\text { Type III collagen }\end{array}$ & $\mathrm{IC}_{50}=15 \mu \mathrm{M}$ & [108] \\
\hline $\begin{array}{c}\text { Oxygen free radicals generated by } \mathrm{H}_{2} \mathrm{O}_{2} \text { induced } \\
\text { damage in human dermal fibroblasts }\end{array}$ & $\mathrm{IC}_{50}=3.17 \mu \mathrm{M}$ & [109] \\
\hline $\mathrm{Cu}^{2+}$-induced human LDL & $\mathrm{IC}_{50}=1 \mu \mathrm{M}$ & [110] \\
\hline Briggs-Rauscher reaction method & $\begin{array}{c}\text { Inhibition time was } 350 \mathrm{~s} \text { and concentration } \\
\text { was } 1.851 \mu \mathrm{M}\end{array}$ & [111] \\
\hline $\begin{array}{l}\text { Inhibition on the autoxidation of linoleic acid in } \\
\text { CTAB micelles }\end{array}$ & $\mathrm{IC}_{50}=10.9 \mu \mathrm{M}$ & [103] \\
\hline $\begin{array}{l}\text { Inhibition of oxidative hemolysis in } \\
\text { mouse erythrocytes }\end{array}$ & $\begin{array}{l}90 \% \text { of Hemolysis inhibition } \\
\text { at } 3.0 \mu \mathrm{M} \text { within } 3 \mathrm{~h}\end{array}$ & [104] \\
\hline
\end{tabular}

ABTS, 2,2'-azino-bis3-ethylbenzthiazoline-6-sulphonic acid; CTAB, cetyl trimethylammonium bromide; EDTA, ethylene diamine tetraacetic acid; LDL, low-density lipoprotein.

Cistanche deserticola is a traditional Chinese medicine (TCM) called "Desert ginseng" in China owing to its excellent medical functions and nourishing effect. According to the theory of TCM, Cistanche deserticola can supplement the kidney, and kidney stores essence and the essence can transform into bone marrow to nourish the bones, which means Cistanche deserticola could promote the formation of the bone [112]. As ECH is the main constituent of Cistanche deserticola, thus maybe possesses anti-osteoporotic property. And in the anti-osteoporotic tests as Table 6 shown, ECH exhibited anti-osteoporotic effect on the promotion of bone formation and suppression of bone resorption [113], and the molecular targets of ECH were also discovered that it could increase the osteoprotegerin (OPG) level and decrease the receptor activator for nuclear factor- $\mathrm{B} B$ Ligand (RANKL) level [114] as well as promoted the phosphorylation of ERK1/2 to activate MAPK/ERK pathway [115,116]; however, the dosage of ECH were so high that even reached at $270 \mathrm{mg} / \mathrm{kg}$ body weight/day, which made some difficult in the future clinical trials and enhanced the medicinal costs. Since the results of the report showed the dosage of $30 \mathrm{mg} / \mathrm{kg}$ body weight/day of ECH was also effective in ovariectomized $(\mathrm{OVX})$ rats, a proper dosage of $\mathrm{ECH}$ in future treatment of osteoporosis disease should be selected with more tests. 
Table 6. Anti-osteoporotic activity of ECH in selected models.

\begin{tabular}{|c|c|c|c|}
\hline Models & Dosage & Activity/Mechanism & Refs \\
\hline $\begin{array}{l}\text { OVX rat model } \\
\text { of osteoporosis }\end{array}$ & $\begin{array}{l}30,90 \text { and } 270 \mathrm{mg} / \mathrm{kg} \text { for } \\
12 \text { weeks, p.o. }\end{array}$ & $\begin{array}{l}\text { Completely corrected the increased urine concentration of } \\
\text { calcium, inorganic phosphorus, and hydroxyproline; } \\
\text { enhanced bone quality, improved total bone mineral } \\
\text { density and biomechanical strength of tibia, promoted the } \\
\text { bone formation and suppressed the bone resorption. }\end{array}$ & [113] \\
\hline $\begin{array}{l}\text { OVX rat model } \\
\text { of osteoporosis }\end{array}$ & $\begin{array}{l}\text { 30, } 90 \text { and } 270 \mathrm{mg} / \mathrm{kg} / \text { day } \\
\text { for } 12 \text { weeks, p.o. }\end{array}$ & $\begin{array}{l}\text { Improved total femur bone mineral density, bone } \\
\text { microarchitecture and biomechanical properties, increased } \\
\text { OPG level, decreased RANKL level; the anti-osteoporotic } \\
\text { activity was similar to phytoestrogen but without } \\
\text { influence the uterus and mammary gland. }\end{array}$ & [114] \\
\hline $\begin{array}{l}\text { Osteoblastic cells and } \\
\text { MC3T3-E1 cells }\end{array}$ & $0.01-100 \mathrm{nM}$ & $\begin{array}{l}\text { Stimulated the cell proliferation of osteoblast, induced } \\
\text { expressions of BMP- } 2 \text { and smad } 4 \text { to activate BMP/smad } \\
\text { pathway, promoted the phosphorylation of ERK } 1 / 2 \text { to } \\
\text { activate MAPK/ERK pathway. }\end{array}$ & [115] \\
\hline Osteoblastic cells & $5 \times 10^{-8}-5 \times 10^{-4} \mathrm{mg} / \mathrm{mL}$ & Increased the expression of BMP-2 protein level. & [116] \\
\hline Osteoblastic cells & $5 \times 10^{-7}-5 \times 10^{-5} \mathrm{mg} / \mathrm{mL}$ & $\begin{array}{l}\text { Up-regulated the expression of OPN mRNA and protein } \\
\text { of osteoblast. }\end{array}$ & [117] \\
\hline $\begin{array}{l}\text { Osteoblastic cells and } \\
\text { MC3T3-E1 cells }\end{array}$ & $0.01-10 \mathrm{nM}$ & $\begin{array}{l}\text { Increased cell proliferation, ALP activity, collagen I } \\
\text { contents, osteocalcin levels, enhanced mineralization in } \\
\text { osteoblasts and the ratio of OPG/RANKL. }\end{array}$ & [18] \\
\hline
\end{tabular}

Table 7. Other activities of ECH in selected models.

\begin{tabular}{|c|c|c|c|}
\hline Other Bioactives & Models/Dosage & Activity/Mechanism & Refs \\
\hline Antidiabetic effect & $\begin{array}{l}\text { Starch-loaded } \\
\text { mice } / 125-500 \mathrm{mg} / \mathrm{kg} \text { for } \\
2 \text { weeks, p.o. }\end{array}$ & $\begin{array}{l}\text { Inhibited the rat lens aldose reductase with } \mathrm{IC}_{50} \text { was } 3.1 \mu \mathrm{M} \text {; } \\
\text { inhibited the increase in postprandial blood glucose levels, } \\
\text { improved glucose tolerance without producing significant } \\
\text { changes in body weight or food intake. }\end{array}$ & [87] \\
\hline Antiviral activity & $\begin{array}{l}\text { Mouse macrophage } \\
\text { model } / 100-1000 \mu \mathrm{g} / \mathrm{mL}\end{array}$ & $\begin{array}{l}\text { Possessed high antiviral activities with different antiviral } \\
\text { profile and limited immune activation properties. }\end{array}$ & [118] \\
\hline $\begin{array}{l}\text { Anti-hepatic fibrosis } \\
\text { effect }\end{array}$ & $\begin{array}{c}\text { Hepatic stellate cell } \\
\text { lines } / 125,250 \text { and } \\
500 \mu \mathrm{g} / \mathrm{mL}\end{array}$ & $\begin{array}{l}\text { Inhibited hepatic stellate cell activation with } \mathrm{IC}_{50} \text { was } 520.3 \\
\mu \mathrm{g} / \mathrm{mL} \text {, suppressed the conduction of the signaling } \\
\text { pathways in transforming growth factor-beta } 1 / \text { smad, } \\
\text { including increasing the mRNA level and protein expression } \\
\text { of smad7, and decreased both the mRNA and protein levels } \\
\text { of smad2 and smad3 in hepatic stellate cell. }\end{array}$ & [119] \\
\hline Anti-tumor activity & $\begin{array}{c}\text { Pancreatic } \\
\text { adenocarcinoma cell } \\
\text { lines } / 20,50,100 \mu \mathrm{M}\end{array}$ & $\begin{array}{l}\text { Inhibited the proliferation of pancreatic adenocarcinoma } \\
\text { cells by inducing the production of reactive oxygen species } \\
\text { and the perturbation of mitochondrial membrane potential } \\
\text { and thus triggering apoptosis, and this activity was main } \\
\text { through modulating MAPK activity. }\end{array}$ & [120] \\
\hline $\begin{array}{l}\text { Testis and sperm injury } \\
\text { protect activity }\end{array}$ & $\begin{array}{l}\text { Testicular and sperm } \\
\text { toxicity induced by BPA/ } \\
6 \mathrm{mg} / \mathrm{kg} \text { for } 6 \text { weeks, p.o. }\end{array}$ & $\begin{array}{l}\text { Reversed BPA-induced abnormality in sperm characteristics, } \\
\text { testicular structure and normalized serum testosterone, } \\
\text { enhanced the testosterone biosynthesis, increased expression } \\
\text { of LDH-x, the key steroidogenic enzymes including StAR, } \\
\text { CYP11A1, 3 } 3 \text {-HSD, 17 } \beta \text {-HSD and CYP17A1. }\end{array}$ & [121] \\
\hline
\end{tabular}

BPA, Bisphenol A; LDH: lactate dehydrogenase; StAR, steroidogenic acute regulatory protein; CYP11A1, cytochrome P450scc; CYP17A1, cytochrome P450 17A1; $3 \beta$-HSD, $3 \beta$-hydroxysteroid dehydrogenase/ $\Delta 5-\Delta 4$ isomerase; $17 \beta$-HSD, $17 \beta$-hydroxysteroid dehydrogenase.

Besides the above significant bioactive, ECH also proved to possess additional antidiabetic effect, antiviral activity, anti-hepatic fibrosis effect, anti-tumor property, testis and sperm injury protect activities as Table 7 shown. 


\section{Discussion}

$\mathrm{ECH}$, a natural PhGs compound has been isolated from dozens of medicinal or horticultural plants, exhibited highly positive activities in treatment of nervous, cardiovascular and bone disorders, especially for the prevention and treatment of a variety of nervous system disorders including Parkinson's and Alzheimer's diseases. Given the above potential in pharmaceutical applications, the preparations of ECH including the classic isolation from herbs, plant cell/tissue culture and even the chemical synthesis have attracted the interests of plenty pharmaceutical scientists. This review has presented the discovery of ECH including its distribution in the plant kingdom, and the preparation of ECH including the methods of classic isolation from medicinal plants, "green cell factories" of plant cell/tissue culture and chemical synthesis, and the pharmacokinetics data of ECH was also posted for further medicinal uses. Then, the most important section of this paper, the remarkable pharmacological properties of ECH were elucidated, including neuroprotective activity, cardioactive property, anti-osteoporotic effect, anti-inflammatory and antioxidant activities. However, there were four important questions should be pay attention before ECH was used for clinical applications: first, both in vivo and in vitro experiments of $\mathrm{ECH}$ reflected its dissatisfied pharmacokinetic property. Concerning the in vivo experiments, ECH exhibited a pitiful fates in the gut, including relatively poor bioavailability [31] (the absolute bioavailability was only $0.83 \%$ ) and rapid rates of metabolism and excretion, following ingestion, ECH appeared in the circulation as phase II metabolites, and its plasma levels rarely exceed $\mathrm{nM}$ concentrations [30]; and in vitro tests showed that $\mathrm{ECH}$ permeated poorly through the Caco-2 monolayers, which implied that ECH was not likely to cross the intestinal and blood brain barriers, thus appeared failed to explain its neuroprotective activity and other bioactive [35]. However, it was reported that in neuronal cells and non-neuronal cells which were exposed to rotenone, ECH was able to cross the blood-brain barrier freely [74]. Second, it should be noted that several of the activities especially the anti-osteoporotic one occurred at relatively high concentrations of ECH (30-270 mg/ $\mathrm{kg} /$ day, orally for 12 weeks) [113], and in the antidiabetic experiments [87], the dose of $\mathrm{ECH}$ even reached at $500 \mathrm{mg} / \mathrm{kg}$ p.o. And others occurred at normal concentrations about 5 to $50 \mathrm{mg} / \mathrm{kg}$. Third, the underlying molecular mechanisms of ECH with neuroprotective and cardiovascular properties, anti-osteoporotic, and anti-inflammatory activities have not been elucidated in detail. Although some common molecular signal pathways and several distinct targets have been disclosed, the responses of molecular targets to $\mathrm{ECH}$ with the above effects remain unclear. Forth, sixty years after the discovery of $\mathrm{ECH}$, to date, very little efforts are done for its clinical trials and the safety and toxicity tests, and reliable clinical data describing the health effects of ECH are limited. Therefore, the in vivo animal studies of ECH should be considered with caution and more clinical trial on its efficacy and safety should be performed.

\section{Conclusions}

In summary, ECH was an inestimable natural product that exhibited highly positive activities in nervous and cardiovascular system disorders as well as bone disease from the wealth of laboratory data, and thus was believed have a promising potential in the treatment of Parkinson's and Alzheimer's diseases, atherosclerosis, osteoporosis, acute colitis, wound injury, and hepatitis. The excellent antioxidant property, which was 9.5-fold greater than Trolox, also implied an ideal application of ECH in the future clinical trials. However, at present, despite the wealth of experimental data that was available describing the potent pharmacological effects of $\mathrm{ECH}$, many issues remain unresolved with respect to effective clinical applications. First, the low bioavailability and extremely fast metabolism of ECH in animals reflected its dissatisfied pharmacokinetic property in the future clinical application. The rapid rates of metabolism and excretion of ECH was due to the multiple metabolic pathways that were involved to eliminate plant-derived toxins, thus further intensive studies are required to confirm the clinical potential of $\mathrm{ECH}$, thereby enabling its acceptance as a therapeutic agent. Another important issue was that, although the present review findings provided a sound basis to confirm that $\mathrm{ECH}$ is a potential candidate for intervention in neurodegenerative diseases such as Alzheimer's 
and Pakinson's disorders, the molecular signal pathways, especially the molecular targets to ECH with the above effects, remain unclear. Thus, further studies are needed to interpret the directed molecular mechanisms. The last issue is also the most important problem, implying that large-scale evidence-based human studies with specific therapeutic settings are necessary. Although plenty of laboratory data shed light on the protection of $\mathrm{ECH}$ against dozens of diseases, the reliable clinical data are limited. More clinical trials on the safety and drugability of ECH are needed.

Funding: This work was supported by the grants from the National Natural Science Foundation of China (No.81560684) and Ningxia key research and invention program of science and technology cooperation of the East and the West (No. 2017BY084).

Conflicts of Interest: The authors declare no conflict of interest.

\section{Abbreviations}

The following abbreviations are used in this manuscript:

\begin{tabular}{|c|c|}
\hline ABTS & 2,2'-azino-bis 3-ethylbenzthiazoline-6-sulphonic acid \\
\hline$A \beta(25-35)$ & amyloid beta-protein fragment $25-35$ \\
\hline AchE & acetylcholinesterase \\
\hline $\mathrm{AD}$ & Alzheimer's disease \\
\hline ALP & alkaline phosphatase \\
\hline ALT & alanine aminotransferase \\
\hline Asp & aspartic acid \\
\hline AST & aspartate aminotransferase \\
\hline ATF3 & activating transcription factors 3 \\
\hline BDNF & brain-derived neurotrophic factor \\
\hline BMD & bone mineral density \\
\hline BMP & bone morphogenetic proteins \\
\hline BPA & bisphenol A \\
\hline $\mathrm{CCl}_{4}$ & carbon tetrachloride \\
\hline ChAT & choline acetyltransferaxe \\
\hline $\mathrm{CHOP}$ & C/EBP-homologous protein \\
\hline СТAB & cetyl trimethylammonium bromide \\
\hline CYP11A1 & cytochrome P450scc \\
\hline CYP17A1 & cytochrome P450 17A1 \\
\hline DA & dopamine \\
\hline DHBA & dihydroxybenzoic acid \\
\hline DOPAC & 3,4-dihydroxyphenyl acetic acid \\
\hline DPPH & 2,2-diphenyl-1-picrylhydrazylhydrate \\
\hline $\mathrm{ECH}$ & echinacoside \\
\hline EDTA & ethylene diamine tetraacetic acid \\
\hline ERK & extracellular signal regulated kinase \\
\hline 5 -FU & 5-fluorouracil \\
\hline GalN/LPS & D-galactosamine/lipopolysaccharide \\
\hline GDNF & glial cell line-derived neurotrophic factor \\
\hline Glu & glutamic acid \\
\hline GSH & glutathione \\
\hline GSH-Px & glutathione peroxidase \\
\hline 5-HT & 5-hydroxytryptamine \\
\hline HPTLC & high-performance thin-layer chromatography \\
\hline HIAA & hydroxyindoleacetic acid \\
\hline $3 \beta-H S D$ & $3 \beta$-hydroxysteroid dehydrogenase $/ \Delta 5-\Delta 4$ isomerase \\
\hline $17 \beta-H S D$ & $17 \beta$-hydroxysteroid dehydrogenase \\
\hline HVA & homovanillic acid \\
\hline HSCCC & high speed countercurrent Chromatography \\
\hline
\end{tabular}


iNOS inducible NO synthase

IL interleukin

LC liquid chromatography

LDH lactate dehydrogenase

LDL low-density lipoprotein

LOD limit of detection

MAPK mitogen-activated protein kinase

MCAO middle cerebral artery occlusion

MDA malondialdehyde

MPP 1-methyl-4-phenylpyridinium

MPTP 1-methyl-4-phenyl-1,2,3,6-tetrahydropyridine

NE norepinephrine

NF-kappa B nuclear factor-kappa B

NO nitric oxide

NOS nitric oxide synthase

6-OHDA 6-hydroxydopamine

OPG osteoprotegerin

OPN osteopontin

OVX ovariectomized

PD Parkinson's disease

PhGs phenylethanoid glycosides

PI3K phosphatidylinositol 3-kinase

RANKL receptor activator for nuclear factor- $\mathrm{k} B$ ligand

ROS reactive oxygen species

SCNA synuclein alpha

SIRT1 silent mating type information regulation 2 homolog-1

SOD superoxide dismutase

StAR steroidogenic acute regulatory protein

TCM traditional Chinese medicine

TGF transforming growth factor

TNF tumor necrosis factor

Trk tropomyosin-related tyrosine kinase

OPG osteoprotegerin

OPN osteopontin

OVX ovariectomized

PD Parkinson's disease

PhGs phenylethanoid glycosides

PI3K phosphatidylinositol 3-kinase

RANKL receptor activator for nuclear factor- $\mathrm{kB}$ ligand

ROS reactive oxygen species

SCNA synuclein alpha

SIRT1 silent mating type information regulation 2 homolog-1

SOD superoxide dismutase

StAR steroidogenic acute regulatory protein

TCM traditional Chinese medicine

TGF transforming growth factor

TNF tumor necrosis factor

Trk tropomyosin-related tyrosine kinase 


\section{References}

1. Alipieva, K.; Korkina, L.; Orhan, I.E.; Georgiev, M.I. Verbascoside-A review of its occurrence, (bio)synthesis and pharmacological significance. Biotechnol. Adv. 2014, 32, 1065-1076. [CrossRef] [PubMed]

2. Stoll, A.; Renz, J.; Brack, A. Isolation and constitution of echinacoside, a glycoside from the roots of Echinacea angustifolia DC. Helv. Chim. Acta 1950, 33, 1877-1893. [CrossRef]

3. Kobayashi, H.; Komatsu, J. Studies on the constituents of Cistanchis herba. 1. Yakugaku Zasshi 1983, 103, 508-511. [CrossRef] [PubMed]

4. Ismail, L.D.; el-Azizi, M.M.; Khalifa, T.I.; Stermitz, F.R. Verbascoside derivatives and iridoid glycosides from Penstemon crandallii. Phytochemistry 1995, 39, 1391-1393. [CrossRef]

5. Zhang, G.G.; Yang, Z.B.; Wang, Y.; Yang, W.R. Effects of Astragalus membranaceus root processed to different particle sizes on growth performance, antioxidant status, and serum metabolites of broiler chickens. Poult. Sci. 2013, 92, 178-183. [CrossRef] [PubMed]

6. Gousiadou, C.; Kokubun, T.; Martins, J.; Gotfredsen, C.H.; Jensen, S.R. Iridoid glucosides in the endemic Picconia azorica (Oleaceae). Phytochemistry 2015, 115, 171-174. [CrossRef] [PubMed]

7. Chen, J.; Cheng, H.; Zhang, J.; Zhang, G.; Ding, W. Investigation on occurrence of lycium barbarum pests and its natural enemies at Ningxia. J. Chin. Med. Mater. 2003, 26, 391-394.

8. Czerwinska, M.E.; Ziarek, M.; Bazylko, A.; Osinska, E.; Kiss, A.K. Quantitative Determination of Secoiridoids and Phenylpropanoids in Different Extracts of Ligustrum Vulgare L. Leaves by a Validated HPTLC-Photodensitometry Method. Phytochem. Anal. 2015, 24, 237-292.

9. Spanakis, M.; Niopas, I. Determination of atenolol in human plasma by HPLC with fluorescence detection: Validation and application in a pharmacokinetic study. J. Chromatogr. Sci. 2013, 51, 128-132. [CrossRef] [PubMed]

10. Dong, Y.; Guo, Q.; Liu, J.; Ma, X. Simultaneous determination of seven phenylethanoid glycosides in Cistanches Herba by a single marker using a new calculation of relative correction factor. J. Sep. Sci. 2018, 1-11. [CrossRef] [PubMed]

11. Andary, C.; Tahrouch, S.; Marion, C.; Wylde, R.; Heitz, A. Caffeic glycoside esters from Jasminum nudiflorum and some related species. Phytochemistry 1992, 31, 885-886. [CrossRef]

12. Xie, J.; Tan, F.; Zhu, J.; Yue, C.; Li, Q. Separation, purification and quantification of verbascoside from Penstemon barbatus (Cav.) Roth. Food Chem. 2012, 135, 2536-2541. [CrossRef] [PubMed]

13. Yang, T.-X.; Lu, Y.-X.; Guo, Y.-H.; Zhai, Z.-X.; Wang, S.-A.; Lu, L.-Q.; Yu, G.-J. Stuided of dry matter accumulation and echinacoside ceontent of Cistanche tubulosa in Hubei plain. China J. Chin. Mater. Med. 2006, 31, 1317-1320.

14. Xie, J.; Deng, J.; Tan, F.; Su, J. Separation and purification of echinacoside from Penstemon barbatus (Can.) Roth by recycling high-speed counter-current chromatography. Life Sci. 2010, 878, 2665-2668. [CrossRef] [PubMed]

15. Perry, N.B.; Burgess, E.J.; Glennie, V.L. Echinacea standardization: Analytical methods for phenolic compounds and typical levels in medicinal species. J. Agric. Food Chem. 2001, 49, 1702-1706. [CrossRef] [PubMed]

16. Xing, Y.-X.; Hu, F.-Z.; Dong, Q.; Peng, M. Determination of echinacoside and acteoside in Tibetan herb Lagotis brevituba Maxim. Chin. J. Pharm. Anal. 2012, 32, 1183-1185, 1195.

17. Yang, T.X.; Zhang, X.H.; Cai, J.Z. Study on secondary metabolic organ of echinacoside in herbs of Cistanche tubulosa. China J. Chin. Mater. Med. 2007, 32, 2591-2594.

18. Li, F.; Yang, Y.; Zhu, P.; Chen, W.; Qi, D.; Shi, X.; Zhang, C.; Yang, Z.; Li, P. Echinacoside promotes bone regeneration by increasing OPG/RANKL ratio in MC3T3-E1 cells. Fitoterapia 2012, 83, 1443-1450. [CrossRef] [PubMed]

19. Dong, B.; Yuan, X.; Zhao, Q.; Feng, Q.; Liu, B.; Guo, Y.; Zhao, B. Ultrasound-assisted aqueous two-phase extraction of phenylethanoid glycosides from Cistanche deserticola Y. C. Ma stems. J. Sep. Sci. 2015, 38, 1194-1203. [CrossRef] [PubMed]

20. Cai, H.; Bao, Z.; Jiang, Y.; Wang, X.Y.; Fan, X.T.; Aierken, M.; Tu, P.F. Study on processing method of Cistanche tubulosa. China J. Chin. Mater. Med. 2007, 32, 1289-1291.

21. Li, F.; Yang, X.; Yang, Y.; Li, P.; Yang, Z.; Zhang, C. Phospholipid complex as an approach for bioavailability enhancement of echinacoside. Drug Dev. Ind. Pharm. 2015, 41, 1777-1784. [CrossRef] [PubMed] 
22. Lim, E.K.; Bowles, D. Plant production systems for bioactive small molecules. Curr. Opin. Biotechnol. 2012, 23, 271-277. [CrossRef] [PubMed]

23. Zhu, Y.H.; Du, F.L.; Zhang, S. Echinacoside determined in Cistanche callus using chlorogenic acid as a internal standard by HPLC. J. Hunan Univ. Chin. Med. 2003, 23, 5-6.

24. Lu, C.T.; Mei, X.G. Improvement of phenylethanoid glycosides production by a fungal elicitor in cell suspension culture of Cistanche deserticola. Biotechnol. Lett. 2003, 25, 1437-1439. [CrossRef] [PubMed]

25. Zhong, L.; Wu, N.-Z. Effect of Echinacoside Content of Cistanche deserticola by Adding Precursors and Revulsant to Hosts. Biotechnology 2011, 21, 76-78.

26. Lv, J.J.; Hu, G.S.; Li, J.K.; Jia, J.M. Effects of precursor feeding and fungal elicitors on secondary metabolits in cell suspension culture of Cistanche deserticola. J. Chin. Med. Mater. 2009, 32, 171-173.

27. Xu, L.S.; Xue, X.F.; Fu, C.X.; Jin, Z.P.; Chen, Y.Q.; Zhao, D.X. Effects of methyl jasmonate and salicylic acid on phenylethanoid glycosides synthesis in suspension cultures of Cistanche deserticola. Chin. J. Biotechnol. 2005, 21, 402-406.

28. Mulani, S.K.; Guh, J.H.; Mong, K.K. A general synthetic strategy and the anti-proliferation properties on prostate cancer cell lines for natural phenylethanoid glycosides. Org. Biomol. Chem. 2014, 12, 2926-2937. [CrossRef] [PubMed]

29. Martin, K.; Appel, C. Polyphenols as dietary supplements: A double-edged sword. Nutr. Diet. Suppl. 2010, 2,1-12. [CrossRef]

30. Del Rio, D.; Rodriguez-Mateos, A.; Spencer, J.P.; Tognolini, M.; Borges, G.; Crozier, A. Dietary (poly) phenolics in human health: Structures, bioavailability, and evidence of protective effects against chronic diseases. Antioxid. Redox Signal. 2013, 18, 1818-1892. [CrossRef] [PubMed]

31. Jia, C.; Shi, H.; Wu, X.; Li, Y.; Chen, J.; Tu, P. Determination of echinacoside in rat serum by reversed-phase high-performance liquid chromatography with ultraviolet detection and its application to pharmacokinetics and bioavailability. J. Chromatogr. B Anal. Technol. Biomed. Life Sci. 2006, 844, 308-313. [CrossRef] [PubMed]

32. Matthias, A.; Addison, R.; Penman, K.; Dickinson, R.; Bone, K.; Lehmann, R. Echinacea alkylamide bioavailability and pharmacokinetics in humans after tablet ingestion. Life Sci. 2005, 77, 2018-2029. [CrossRef] [PubMed]

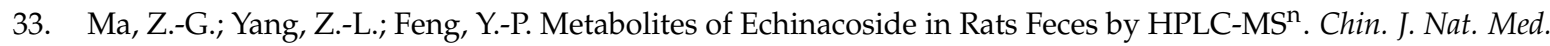
2008, 6, 387-390. [CrossRef]

34. Lei, L.; Song, Z.H.; Tu, P.F.; Li, Y.Z.; Wu, L.J.; Chen, F.K. Metabolic regulation of phenylethanoid glycosides from Herba cistanches in dogs' gastrointestine. Acta Pharm. Sin. 2001, 36, 432-435.

35. Matthias, A.; Blanchfield, J.T.; Penman, K.G.; Toth, I.; Lang, C.S.; De Voss, J.J.; Lehmann, R.P. Permeability studies of alkylamides and caffeic acid conjugates from echinacea using a Caco-2 cell monolayer model. J. Clin. Pharm. Ther. 2004, 29, 7-13. [CrossRef] [PubMed]

36. Matthias, A.; Penman, K.; Matovic, N.; Bone, K.; De Voss, J.; Lehmann, R. Bioavailability of Echinacea constituents: Caco-2 monolayers and pharmacokinetics of the alkylamides and caffeic acid conjugates. Molecules 2005, 10, 1242-1251. [CrossRef] [PubMed]

37. Gao, Y.; Zong, C.; Liu, F.; Fang, L.; Cai, R.; Shi, Y.; Chen, X.; Qi, Y. Evaluation of the intestinal transport of a phenylethanoid glycoside-rich extract from Cistanche deserticola across the Caco-2 cell monolayer model. PLoS ONE 2015, 10, e0116490. [CrossRef] [PubMed]

38. Wei, L.-L.; Chen, H.; Jiang, Y.; Tu, P.-F.; Zhong, M.; Liu, F.; Liu, C.-Y. Determination of ECH on cerebral ischemia injury rat plasma and brain tissue by HPLC method. Chin. Pharmacol. Bull. 2011, 27, 737-738.

39. Zhou, J.; Zeng, P.; Sun, J.B.; Wang, F.Q.; Zhang, Q. Application of two-phase hollow fiber liquid phase microextraction coupled with high-performance liquid chromatography for the study of the echinacoside pharmacokinetics in Parkinson's disease rat plasma. J. Pharm. Biomed. Anal. 2013, 81-82, 27-33. [CrossRef] [PubMed]

40. Lu, H. Resolution of carotenoid isomers in Lycium barbarum L. by heuristic evolving latent projection. Chin. J. Chromatogr. 2005, 23, 415-417.

41. Zhang, W.-X.; Ma, J.-Y.; Chen, H.; Jiang, Y.; Tu, P.-F.; Ding, H. Effect of echinacoside on striatal and hippocampus extracellular fluid of monoamine neurotransmitter in Parkinson's disease rats. Chin. Pharmacol. Bull. 2014, 30, 1131-1136. 
42. Chen, H.; Jing, F.C.; Li, C.L.; Tu, P.F.; Zheng, Q.S.; Wang, Z.H. Echinacoside prevents the striatal extracellular levels of monoamine neurotransmitters from diminution in 6-hydroxydopamine lesion rats. J. Ethnopharmacol. 2007, 114, 285-289. [CrossRef] [PubMed]

43. Jing, F.-C.; Chen, H.; Li, C.-L.; Yan, M.-Y. Effects of echinacoside on striatal extracellular levels of monomines neurotransmitters in 6-hydroxydopamine lesion rats. Chin. Pharmacol. Bull. 2007, 23, 1305-1308.

44. Wang, Y.H.; Xuan, Z.H.; Tian, S.; Du, G.H. Echinacoside Protects against 6-Hydroxydopamine-Induced Mitochondrial Dysfunction and Inflammatory Responses in PC12 Cells via Reducing ROS Production. Evid. Based Complement. Alternat. Med. 2015, 189239. [CrossRef] [PubMed]

45. Zhao, Q.; Gao, J.; Li, W.; Cai, D. Neurotrophic and neurorescue effects of Echinacoside in the subacute MPTP mouse model of Parkinson's disease. Brain Res. 2010, 1346, 224-236. [CrossRef] [PubMed]

46. Zhao, X.; Pu, X.-P.; Geng, X.-C. Effects of echinacoside on protein expression from substantia nigra and striatal tissue in mouse MPTP model of Parkinsons disease by using 2-dimensional electrophoresis analysis. Chin. Pharmacol. Bull. 2008, 24, 28-32.

47. Zhang, J.; Zhang, Z.; Xiang, J.; Cai, M.; Yu, Z.; Li, X.; Wu, T.; Cai, D. Neuroprotective Effects of Echinacoside on Regulating the Stress-Active p38MAPK and NF-kappaB p52 Signals in the Mice Model of Parkinson's Disease. Neurochem. Res. 2017, 42, 975-985. [CrossRef] [PubMed]

48. Geng, X.; Tian, X.; Tu, P.; Pu, X. Neuroprotective effects of echinacoside in the mouse MPTP model of Parkinson's disease. Eur. J. Pharmacol. 2007, 564, 66-74. [CrossRef] [PubMed]

49. Zhao, Q.; Yang, X.; Cai, D.; Ye, L.; Hou, Y.; Zhang, L.; Cheng, J.; Shen, Y.; Wang, K.; Bai, Y. Echinacoside Protects Against MPP(+)-Induced Neuronal Apoptosis via ROS/ATF3/CHOP Pathway Regulation. Neurosci. Bull. 2016, 32, 349-362. [CrossRef] [PubMed]

50. Wu, C.R.; Lin, H.C.; Su, M.H. Reversal by aqueous extracts of Cistanche tubulosa from behavioral deficits in Alzheimer's disease-like rat model: Relevance for amyloid deposition and central neurotransmitter function. BMC Complement. Altern. Med. 2014, 14, 202. [CrossRef] [PubMed]

51. Ding, H.; Chen, H.; Jiang, Y.; Tu, P.-F.; Ma, J.-Y.; Zhang, W.-X. Effects of echinacoside on monoamine neurotransmitters in hippocampus and cortex of rats with Alzheimer's disease. Chin. Pharmacol. Bull. 2014, 30, 1564-1569.

52. Liu, C.-L.; Chen, H.; Jiang, Y.; Tu, P.-F. Effects of echinacoside on behavior, oxygen free radical and cholinergic neurotransmitter metabolism rate of the rat model of vascular dementia. Chin. Pharmacol. Bull. 2013, 29, 1035-1036.

53. Ding, H.; Chen, H.; Jiang, Y.; Tu, P.-F.; Ma, J.-Y.; Zhang, W.-X. Effect of echinacoside on learning-memory ability and oxygen free radicals on model rats with Alzheimer's disease. Chin. Pharmacol. Bull. 2014, 30, 1302-1305.

54. Tian, F.; Zhang, K.; Kang, A.-J.; Jiang, Y.; Zhou, S.-P.; Zheng, Z.-H. The Effect and Mechanism of Echinacoside on SAM-P/8's Learning and Memory Ability. Lab. Anim. Sci. Manag. 2006, 23, 14-15, 21.

55. Liu, C.-L.; Chen, H.; Jiang, Y.; Tu, P.-F.; Zhong, M.; Ma, J.-Y.; Ding, H.; Zhang, W.-X.; Jin, X.-M. Effects of echinacoside on extracellular acetylcholine and choline levels of hippocampus and striatum of cerebral ischemia rats. Acta Pharmacol. Sin. 2013, 48, 790-793.

56. Zhang, D.; Li, H.; Wang, J.B. Echinacoside inhibits amyloid fibrillization of HEWL and protects against Abeta-induced neurotoxicity. Int. J. Biol. Macromol. 2015, 72, 243-253. [CrossRef] [PubMed]

57. Qi, X.-L.; Xiao, H.-T.; Xiao, Y.; Hao, X.-Y.; Guang, Z.-Z. Effects of Echinacoside and Isoacteoside on the Expression of Nicotinic Receptors in Neuroblastoma Cells. Lishizhen Med. Mater. Med. Res. 2011, 22, 1561-1563.

58. Zhu, M.; Zhou, M.; Shi, Y.; Li, W.W. Effects of echinacoside on MPP(+)-induced mitochondrial fragmentation, mitophagy and cell apoptosis in SH-SY5Y cells. Chin. J. Integr. Med. 2012, 10, 1427-1432. [CrossRef] [PubMed]

59. Deng, M.; Zhao, J.Y.; Tu, P.F.; Jiang, Y.; Chen, J. Echinacoside rescues the SHSY5Y neruonal cells from TNFa-induced apoptosis. Chin. Pharmacol. Bull. 2005, 21, 169-174.

60. Deng, M.; Zhao, J.Y.; Tu, P.F.; Jiang, Y.; Li, Z.B.; Wang, Y.H. Echinacoside rescues the SHSY5Y neuronal cells from TNFalpha-induced apoptosis. Eur. J. Pharmacol. 2004, 505, 11-18. [CrossRef] [PubMed]

61. Shen, L.; Chen, H.; Zhu, Q.; Wang, Y.; Wang, S.; Qian, J.; Wang, Y.; Qu, H. Identification of bioactive ingredients with immuno-enhancement and anti-oxidative effects from Fufang-Ejiao-Syrup by LC-MS(n) combined with bioassays. J. Pharm. Biomed. Anal. 2016, 117, 363-371. [CrossRef] [PubMed] 
62. Kuang, R.; Sun, Y.; Yuan, W.; Lei, L.; Zheng, X. Protective effects of echinacoside, one of the phenylethanoid glycosides, on $\mathrm{H}_{2} \mathrm{O}_{2}$-induced cytotoxicity in PC12 cells. Planta Med. 2009, 75, 1499-1504. [CrossRef] [PubMed]

63. Kuang, R.; Sun, Y.; Zheng, X. Suppression of nitric oxide implicated in the protective effect of echinacoside on $\mathrm{H}_{2} \mathrm{O}_{2}$-induced PC12 cell injury. Nat. Prod. Commun. 2010, 5, 571-574. [PubMed]

64. Kuang, R.; Sun, Y.-G.; Deng, T.-L.; Zheng, X.-X. The protective effect and mechanisms of echinacoside on $\mathrm{H}_{2} \mathrm{O}_{2}$-injured PC12 cells. Chin. Pharmacol. Bull. 2009, 25, 515-518.

65. Lu, C.W.; Lin, T.Y.; Huang, S.K.; Wang, S.J. Echinacoside Inhibits Glutamate Release by Suppressing Voltage-Dependent $\mathrm{Ca}(2+)$ Entry and Protein Kinase $\mathrm{C}$ in Rat Cerebrocortical Nerve Terminals. Int. J. Mol. Sci. 2016, 17. [CrossRef] [PubMed]

66. Zhong, M.; Liu, C.-L.; Chen, H.; Jiang, Y.; Tu, P.F.; Wei, L.-L.; Liu, F. Effects of Echinacoside on Striatal Extracellular Levels of Hydroxyl Radical in Cerebral Ischemia Rats. Chin. Pharm. J. 2012, 47, 343-346.

67. Zhong, M.; Chen, H.; Jiang, Y.; Tu, P.F.; Liu, C.-L.; Zhang, W.-X.; Ma, J.-Y.; Ding, H. Effects of echinacoside on striatal extracellular levels of amino acid neurotransmitter in cerebral ischemia rats. Chin. Pharmacol. Bull. 2012, 28, 361-365.

68. Zhong, M.; Chen, H.; Jiang, Y.; Tu, P.F.; Liu, C.-L.; Wei, L.-L. Effects of echinacoside on monoamine neurotransmitters in bilateral brain tissue of rats with cerebral ischemia. Chin. J. New Drugs 2012, $21,1283-1287$.

69. Wei, L.-L.; Chen, H.; Jiang, Y.; Tu, P.F.; Du, J.; Zhong, M.; Liu, F.; Liu, C.-L. Effects of echinacoside on Lipid Peroxidation in Cerebral Ischemia Rats. Chin. J. Inf. TCM 2011, 18, 36-37.

70. Du, J.; Chen, H.; Jiang, Y.; Tu, P.F. Protective effect of echinacoside on cerebral ischemia rats. Lishizhen Med. Mater. Med. Res. 2010, 21, 1324-1325.

71. Wei, L.L.; Chen, H.; Jiang, Y.; Tu, P.F.; Zhong, M.; Du, J.; Liu, F.; Wang, L.; Liu, C.Y. Effects of echinacoside on histio-central levels of active mass in middle cerebral artery occlusion rats. Biomed. Environ. Sci. 2012, 25, 238-244. [PubMed]

72. Wei, L.L.; Chen, H.; Jiang, Y.; Tu, P.F.; Zhong, M.; Du, J.; Liu, F.; Liu, C.Y.; Wang, L. Effects of echinacoside on striatal extracellular levels of monoamine neurotransmitter in cerebral ischemia rats. Chin. Pharmacol. Bull. 2011, 27, 174-177.

73. Feng, X.Y.; Zhu, M.; Zhang, Q.Q.; Chen, Y.P.; Li, W.W. Selective protection of nigral dopaminergic neurons by echinacoside in a rat model of Parkinson disease induced by rotenone. J. Chin. Integr. Med. 2012, 10, 777-783. [CrossRef]

74. Zhu, M.; Lu, C.; Li, W. Transient exposure to echinacoside is sufficient to activate Trk signaling and protect neuronal cells from rotenone. J. Neurochem. 2013, 124, 571-580. [CrossRef] [PubMed]

75. Ma, J.-Y.; Zhang, W.-X.; Chen, H.; Jiang, Y.; Tu, P.F.; Ding, H. The protective effects of echinacoside on oxidative stress injury in vascular dementia rats. Chin. Pharmacol. Bull. 2014, 30, 638-642.

76. Gulinuer, M.; Lei, L.; Tu, P.F.; Guo, D.; Lu, J.-F. Study on Molecular Mechanism of Echinacoside for Against Aging. Acta Biochim. Biophys. Sin. 2004, 20, 183-187.

77. Li, Y.; Song, Y.-Y.; Chu, C.-M.; Zhang, H.-Q. Study on the Anti-aging Effect of Echinacoside. Chin. Pharm. J. 2011, 46, 1077-1080.

78. Li, Y.; Song, Y.-Y.; Zhang, H.-Q. Effect of Echinacoside on immune function and mitochondrial DNA relative content of aging mice. Chin. Pharmacol. Bull. 2010, 26, 810-813.

79. Zhang, A.-X.; Lv, W.-H.; Xu, S.; Zhang, H.-Q. Study on the anti-oxidation effect of echinacoside. Pract. Geriatr. 2009, 23, 310-312.

80. Zhu, H.; Cheng, C.; Zhang, C.; Wang, Z. Echinacoside suppresses cellular senscence of human fibroblastic cells by down-regulation of p53. J. Chin. Pharm. Sci. 2011, 20, 523-528. [CrossRef]

81. Xie, H.; Zhu, H.; Cheng, C.; Liang, Y.; Wang, Z. Echinacoside retards cellular senescence of human fibroblastic cells MRC-5. Pharmazie 2009, 64, 752-754. [PubMed]

82. Lindner, A.; Santilli, D.; Hodgett, J.; Nerlinger, C. Effects of 5-Fluorouracil on the Hematopoietic System of the Mouse. Cancer Res. 1960, 20, 497-502. [PubMed]

83. Wang, S.; Zheng, G.; Tian, S.; Zhang, Y.; Shen, L.; Pak, Y.; Shen, Y.; Qian, J. Echinacoside improves hematopoietic function in 5-FU-induced myelosuppression mice. Life Sci. 2015, 123, 86-92. [CrossRef] [PubMed] 
84. Gai, X.Y.; Tang, F.; Ma, J.; Zeng, K.W.; Wang, S.L.; Wang, Y.P.; Wuren, T.N.; Lu, D.X.; Zhou, Y.; Ge, R.L. Antiproliferative effect of echinacoside on rat pulmonary artery smooth muscle cells under hypoxia. J. Pharmacol. Sci. 2014, 126, 155-163. [CrossRef] [PubMed]

85. Li, H.; Song, A.-Q.; Xue, J.-H.; Zhou, Y.-H. Protective effect of echinacoside on vascular endothelial cells. J. Xi'an Jiaotong Univ. Med. Sci. 2013, 34, 387-392.

86. He, W.J.; Fang, T.H.; Ma, X.; Zhang, K.; Ma, Z.Z.; Tu, P.F. Echinacoside elicits endothelium-dependent relaxation in rat aortic rings via an NO-cGMP pathway. Planta Med. 2009, 75, 1400-1404. [CrossRef] [PubMed]

87. Morikawa, T.; Ninomiya, K.; Imamura, M.; Akaki, J.; Fujikura, S.; Pan, Y.; Yuan, D.; Yoshikawa, M.; Jia, X.; $\mathrm{Li}, \mathrm{Z}$; ; et al. Acylated phenylethanoid glycosides, echinacoside and acteoside from Cistanche tubulosa, improve glucose tolerance in mice. J. Nat. Med. 2014, 68, 561-566. [CrossRef] [PubMed]

88. Jia, Y.; Guan, Q.; Jiang, Y.; Salh, B.; Guo, Y.; Tu, P.; Du, C. Amelioration of Dextran Sulphate Sodium-Induced Colitis in Mice by Echinacoside-Enriched Extract of Cistanche tubulosa. Phytother. Res. 2014, 28, 110-119. [CrossRef] [PubMed]

89. Morikawa, T.; Pan, Y.; Ninomiya, K.; Imura, K.; Matsuda, H.; Yoshikawa, M.; Yuan, D.; Muraoka, O. Acylated phenylethanoid oligoglycosides with hepatoprotective activity from the desert plant Cistanche tubulosa. Bioorg. Med. Chem. 2010, 18, 1882-1890. [CrossRef] [PubMed]

90. Wu, Y.; Xu, G.-L.; Lou, M.; Zeng, Z. The protective effect of echinacoside on acute liver injury in rats. Chin. J. Gastroenterol. Hepatol. 2008, 17, 410-412.

91. Jia, Y.; Guan, Q.; Guo, Y.; Du, C. Echinacoside stimulates cell proliferation and prevents cell apoptosis in intestinal epithelial MODE-K cells by up-regulation of transforming growth factor-beta1 expression. J. Pharmacol. Sci. 2012, 118, 99-108. [CrossRef] [PubMed]

92. Xiong, Q.; Tezuka, Y.; Kaneko, T.; Li, H.; Tran, L.Q.; Hase, K.; Namba, T.; Kadota, S. Inhibition of nitric oxide by phenylethanoids in activated macrophages. Eur. J. Pharmacol. 2000, 400, 137-144. [CrossRef]

93. Speroni, E.; Govoni, P.; Guizzardi, S.; Renzulli, C.; Guerra, M.C. Anti-inflammatory and cicatrizing activity of Echinacea pallida Nutt. root extract. J. Ethnopharmacol. 2002, 79, 265-272. [CrossRef]

94. Rousseau, B.; Tateya, I.; Lim, X.; Munoz-del-Rio, A.; Bless, D.M. Investigation of anti-hyaluronidase treatment on vocal fold wound healing. J. Voice 2006, 20, 443-451. [CrossRef] [PubMed]

95. Li, X.; Gou, C.; Yang, H.; Qiu, J.; Gu, T.; Wen, T. Echinacoside ameliorates D-galactosamine plus lipopolysaccharide-induced acute liver injury in mice via inhibition of apoptosis and inflammation. Scand. J. Gastroenterol. 2014, 49, 993-1000. [CrossRef] [PubMed]

96. Wu, Y.; Li, L.; Wen, T.; Li, Y.Q. Protective effects of echinacoside on carbon tetrachloride-induced hepatotoxicity in rats. Toxicology 2007, 232, 50-56. [CrossRef] [PubMed]

97. Senchina, D.S.; Strauch, J.H.; Hoffmann, G.B.; Shah, N.B.; Laflen, B.K.; Dumke, B.L.; Dao, C.T.; Dias, A.S.; Perera, M.A. Phytochemical and immunomodulatory properties of an Echinacea laevigata (Asteraceae) tincture. J. Altern. Complement. Med. 2011, 17, 375-377. [CrossRef] [PubMed]

98. Pellati, F.; Benvenuti, S.; Magro, L.; Melegari, M.; Soragni, F. Analysis of phenolic compounds and radical scavenging activity of Echinacea spp. J. Pharm. Biomed. Anal. 2004, 35, 289-301. [CrossRef]

99. Sloley, B.D.; Urichuk, L.J.; Tywin, C.; Coutts, R.T.; Pang, P.K.; Shan, J.J. Comparison of chemical components and antioxidants capacity of different Echinacea species. J. Pharm. Pharmacol. 2001, 53, 849-857. [CrossRef] [PubMed]

100. Wang, P.; Zheng, R.; Gao, J.; Jia, Z.; Wang, W.; Yao, S.; Zhang, J.; Lin, N. Reaction of hydroxyl radical with phenylpropanoid glycosides from Pedicularis species: A pulse radiolysis study. Chin. Acad. Sci. 1996, 39, 154-158.

101. Tai, B.H.; Jung, B.Y.; Cuong, N.M.; Linh, P.T.; Tung, N.H.; Nhiem, N.X.; Huong, T.T.; Anh, N.T.; Kim, J.A.; Kim, S.K.; et al. Total peroxynitrite scavenging capacity of phenylethanoid and flavonoid glycosides from the flowers of Buddleja officinalis. Biol. Pharm. Bull. 2009, 32, 1952-1956. [CrossRef] [PubMed]

102. Hu, G.S.; Hur, Y.J.; Jia, J.M.; Lee, J.H.; Chung, Y.S.; Yi, Y.B.; Yun, D.J.; Park, S.K.; Kim, D.H. Effects of 2-aminoindan-2-phosphonic acid treatment on the accumulation of salidroside and four phenylethanoid glycosides in suspension cell culture of Cistanche deserticola. Plant Cell Rep. 2011, 30, 665-674. [CrossRef] [PubMed]

103. Zheng, R.L.; Wang, P.F.; Li, J.; Liu, Z.M.; Jia, Z.J. Inhibition of the autoxidation of linoleic acid by phenylpropanoid glycosides from Pedicularis in micelles. Chem. Phys. Lipids 1993, 65, 151-154. [CrossRef] 
104. Li, J.; Wang, P.F.; Zheng, R.; Liu, Z.M.; Jia, Z. Protection of phenylpropanoid glycosides from Pedicularis against oxidative hemolysis in vitro. Planta Med. 1993, 59, 315-317. [PubMed]

105. Mucaji, P.; Zahradnikova, A.; Bezakova, L.; Cupakova, M.; Rauova, D.; Nagy, M. HPLC determination of antilipoxygenase activity of a water infusion of Ligustrum vulgare L. leaves and some of its constituents. Molecules 2011, 16, 8198-8208. [CrossRef] [PubMed]

106. Xiong, Q.; Kadota, S.; Tani, T.; Namba, T. Antioxidative effects of phenylethanoids from Cistanche deserticola. Biol. Pharm. Bull. 1996, 19, 1580-1585. [CrossRef] [PubMed]

107. Sgarbossa, A.; Dal Bosco, M.; Pressi, G.; Cuzzocrea, S.; Dal Toso, R.; Menegazzi, M. Phenylpropanoid glycosides from plant cell cultures induce heme oxygenase 1 gene expression in a human keratinocyte cell line by affecting the balance of NRF2 and BACH1 transcription factors. Chem. Biol. Interact. 2012, 199, 87-95. [CrossRef] [PubMed]

108. Facino, R.M.; Carini, M.; Aldini, G.; Saibene, L.; Pietta, P.; Mauri, P. Echinacoside and caffeoyl conjugates protect collagen from free radical-induced degradation: A potential use of Echinacea extracts in the prevention of skin photodamage. Planta Med. 1995, 61, 510-514. [CrossRef] [PubMed]

109. Mensah, A.Y.; Sampson, J.; Houghton, P.J.; Hylands, P.J.; Westbrook, J.; Dunn, M.; Hughes, M.A.; Cherry, G.W. Effects of Buddleja globosa leaf and its constituents relevant to wound healing. J. Ethnopharmacol. 2001, 77, 219-226. [CrossRef]

110. Dalby-Brown, L.; Barsett, H.; Landbo, A.K.; Meyer, A.S.; Molgaard, P. Synergistic antioxidative effects of alkamides, caffeic acid derivatives, and polysaccharide fractions from Echinacea purpurea on in vitro oxidation of human low-density lipoproteins. J. Agric. Food Chem. 2005, 53, 9413-9423. [CrossRef] [PubMed]

111. Cervellati, R.; Renzulli, C.; Guerra, M.C.; Speroni, E. Evaluation of antioxidant activity of some natural polyphenolic compounds using the Briggs-Rauscher reaction method. J. Agric. Food Chem. 2002, 50, 7504-7509. [CrossRef] [PubMed]

112. Wang, T.; Zhang, X.; Xie, W. Cistanche deserticola YC Ma, “Desert ginseng": A review. Am. J. Chin. Med. 2012, 40, 1123-1141. [CrossRef] [PubMed]

113. Li, F.; Yang, X.; Yang, Y.; Guo, C.; Zhang, C.; Yang, Z.; Li, P. Antiosteoporotic activity of echinacoside in ovariectomized rats. Phytomedicine 2013, 20, 549-557. [CrossRef] [PubMed]

114. Yang, X.; Li, F.; Yang, Y.; Shen, J.; Zou, R.; Zhu, P.; Zhang, C.; Yang, Z.; Li, P. Efficacy and safety of echinacoside in a rat osteopenia model. Evid. Based Complement. Alternat. Med. 2013, 2013, 926928. [CrossRef] [PubMed]

115. Fang, H.-L.; Li, J.-X.; Yao, L.-M.; Tao, Z. Echinacoside promotes cell proliferation of rat osteoblast through activating of ERK/BMP-2 signaling pathway. Med. Forum 2015, 19, 435-438.

116. Xing, X.X.; Liu, Z.-J.; Han, B. Effects of Acteoside and Echinacoside on the Expression of the BMP2 in Rat Osteoblast. Prog. Vet. Med. 2011, 32, 45-48.

117. Li, C.-H.; Liu, Z.-J.; Zheng, S.-J.; Han, B.; Wang, J.-F. Effect of Echinacoside on the Expression of the OPN mRNA and Protein in Rat Osteoblasts in vitro. Chin. Anim. Husb. Vet. Med. 2013, 40, 50-55.

118. Vohra, S.; Adams, D.; Hudson, J.B.; Moore, J.A.; Vimalanathan, S.; Sharma, M.; Burt, A.J.; Lamont, E.; Lacaze, N.; Arnason, J.T.; et al. Selection of natural health products for clinical trials: A preclinical template. Can. J. Physiol. Pharmacol. 2009, 87, 371-378. [CrossRef] [PubMed]

119. You, S.P.; Ma, L.; Zhao, J.; Zhang, S.L.; Liu, T. Phenylethanol Glycosides from Cistanche tubulosa Suppress Hepatic Stellate Cell Activation and Block the Conduction of Signaling Pathways in TGF-beta1/smad as Potential Anti-Hepatic Fibrosis Agents. Molecules 2016, 21, 102. [CrossRef] [PubMed]

120. Wang, W.; Luo, J.; Liang, Y.; Li, X. Echinacoside suppresses pancreatic adenocarcinoma cell growth by inducing apoptosis via the mitogen-activated protein kinase pathway. Mol. Med. Rep. 2016, 13, 2613-2618. [CrossRef] [PubMed]

121. Jiang, Z.; Wang, J.; Li, X.; Zhang, X. Echinacoside and Cistanche tubulosa (Schenk) R. wight ameliorate bisphenol A-induced testicular and sperm damage in rats through gonad axis regulated steroidogenic enzymes. J. Ethnopharmacol. 2016, 193, 321-328. [CrossRef] [PubMed]

(C) 2018 by the authors. Licensee MDPI, Basel, Switzerland. This article is an open access article distributed under the terms and conditions of the Creative Commons Attribution (CC BY) license (http:/ / creativecommons.org/licenses/by/4.0/). 